Article

\title{
Laboratory Assessment and In-Field Monitoring of Macro-Encapsulated Phase Change Materials for Building Envelope Applications
}

\author{
Stefano Fantucci *(D), Giorgia Autretto, Elisa Fenoglio, Emanuela Sassaroli and Marco Perino
}

Citation: Fantucci, S.; Autretto, G.; Fenoglio, E.; Sassaroli, E.; Perino, M Laboratory Assessment and In-Field Monitoring of Macro-Encapsulated Phase Change Materials for Building Envelope Applications. Appl. Sci. 2022, 12, 2054. https://doi.org/ 10.3390/app12042054

Academic Editor: Cesare Biserni

Received: 14 December 2021

Accepted: 10 February 2022

Published: 16 February 2022

Publisher's Note: MDPI stays neutral with regard to jurisdictional claims in published maps and institutional affiliations.

Copyright: (C) 2022 by the authors. Licensee MDPI, Basel, Switzerland. This article is an open access article distributed under the terms and conditions of the Creative Commons Attribution (CC BY) license (https:// creativecommons.org/licenses/by/ $4.0 /)$.
TEBE Research Group, Department of Energy, Politecnico di Torino, 10129 Torino, Italy; giorgia.autretto@polito.it (G.A.); elisa.fenoglio@polito.it (E.F.); emanuela.sassaroli@studenti.polito.it (E.S.); marco.perino@polito.it (M.P.)

* Correspondence: stefano.fantucci@polito.it

\begin{abstract}
Phase Change Material (PCM) based products represent an emerging technology for the building sector. For their application in the building envelope, they are usually macro-encapsulated in plastic/metal containers or placed in bags/pouches that allow an easier and safer installation. Unfortunately, most of the product data on PCMs are obtained by means of the differential scanning calorimetry method (DSC) applied to bulk PCMs. This method, even though accurate, can lead to results that are not fully representative of the complex behavior of PCM-based products. The results of an experimental laboratory campaign, aimed at characterizing the thermal properties of a full-scale PCM product, are presented in this paper. Tests were carried out on a commercial macro-encapsulated PCM considering three different melting temperatures. The obtained results show that the overall equivalent thermal properties of the macro-encapsulated PCM products maybe somewhat different from those of bulk PCMs. In a second step, two PCM products were selected and applied to a parallel roof testing room system, directly exposed to the outdoor environment. The results of the monitoring of this system have demonstrated the effectiveness of PCMs in reducing the peak heat gains through the roof components by up to $48 \%$. Nevertheless, by comparing the laboratory results with the monitored data, it was also possible to observe that the latent heat capacity of the PCM was never fully exploited. Thus, greater benefits could be achieved in different monitoring periods, or if a PCM with a lower melting temperature were adopted.
\end{abstract}

Keywords: phase change materials; macro encapsulated; roof; heat storage; energy retrofitting; thermal conductivity; enthalpy; building envelope; test room

\section{Introduction}

The increasing demand for comfortable and more energy efficient buildings has generated growing interest in the development and application of new materials and technologies for the building envelope, especially for the energy retrofitting of existing buildings and for the design of new nearly Zero Energy Buildings (nZEB).

One of the passive approaches used to improve building energy efficiency and indoor thermal comfort is to develop envelope solutions that implement phase change materials (PCMs). These materials are very attractive since they are able to increase the thermal inertia by exploiting their latent heat thermal storage capacity during their phase change. Thus, they are able to store energy over a certain range of temperatures that correspond to the phase transition temperature of the material [1,2].

As a result of the high latent heat capacity of PCMs, their integration into building envelopes improves the thermal comfort of a building by minimizing the internal temperature peaks and fluctuations. This provides several benefits, such as the prevention of building overheating, with a consequent reduction of the cooling loads, which in turn allows the technical equipment used for cooling to be downsized [1,3]. Furthermore, in the 
winter season, they allow a better exploitation of renewable energy sources (solar energy), because they are able to minimize the mismatch between solar energy production and its usage by shifting and reducing the energy heating demand [4-6].

PCMs can be incorporated into all the building envelope components: walls, roofs, windows and floors. Four techniques that can be used to incorporate PCMs into building envelopes have been presented in the literature: direct incorporation, impregnation, encapsulation and shape stabilization $[7,8]$. In almost all cases, the PCM has to be encapsulated for technical use to avoid problems, such as the leaking of the PCMs and/or the diffusion of liquids through the building materials [1,9], which can cause surface discoloration and other issues.

There are two main ways of encapsulating PCMs:

- microencapsulation, which consists in packing the PCM materials into capsules which can range in size from less than $1 \mu \mathrm{m}$ to around $300 \mu \mathrm{m}$ [10];

- macro encapsulation, which involves encapsulating PCMs in any type of container, such as tubes, spheres or panels, capsule stripes, or aluminum profiles, which are usually larger than $1 \mathrm{~cm}$.

In the latter case, the containers can be incorporated into building materials or be used as heat exchangers by themselves [1,9].

A typical solution is that of using metal or plastic film packages, which have become the most established technologies in recent decades for building applications (especially in walls and roofs) and which have a relatively low cost [11-13].

Several PCM materials have been studied in the last few years, that is salt hydrates (inorganic), paraffin waxes (organic), fatty acids and eutectic compounds. Among these materials, salt hydrates are interesting for use in building envelopes because of their lack of or limited risk of catching fire [3,14], their high volumetric storage capacity, higher thermal conductivity than that of organic PCMs, low volume change on phase transition and lower operating costs than paraffin waxes. On the other hand, inorganic PCMs introduce a corrosive behavior to metals, thus leading to a higher cost. [3]

The application of PCMs to buildings, and especially to roofs, seems to be a promising solution to reduce the energy demands of such buildings and to minimize the thermal discomfort conditions. The roof in low-rise buildings is the largest area exposed to solar radiation, and thus the space below it (the attic) is subject to higher summer heat loads and presents a high risk of overheating $[15,16]$.

Several studies have investigated the potential of PCMs in building roofs and have highlighted their contribution to building energy saving in different locations. Kośny [11] reported the results of some experiments, carried out between 1994 and 2010 in the USA, Brazil and India, on the integration of macro encapsulation PCMs as a part of attic insulation systems. In these tests, it emerged that the major advantage of PCM-enhanced insulations is their capacity to significantly reduce and shift the peak thermal loads. In general, the author observed relevant percentage reductions (of up to $44 \%$ ), in terms of thermal loads and heat flux peaks, compared with a conventional roof without any PCM.

PCMs placed on the roof are able to absorb part of the incoming solar energy and thermal energy from the surrounding environment, thus reducing temperature fluctuations in the indoor environment [1].

Pasupathy et al. [17] carried out a detailed experiment, which lasted a full year, to analyze the thermal performance of the roof of a building that incorporated PCMs in Chennai, India. The experiment involved two identical test rooms to study the effects of PCM panels on the roof of the building. One of these rooms was constructed without PCM on the roof in order to have a reference case for comparison with the experimental room that included the phase change material. The results show that the PCM panel on the roof narrowed the indoor air temperature swings. The adopted solution performed well throughout all the seasons, especially when the top panel had a $6-7^{\circ} \mathrm{C}$ higher melting temperature than the indoor temperature in the early morning during the peak summer month, and the bottom panel had a melting temperature near the desired ambient temperature. 
Alqallaf et al. [18] conducted an experiment on the concrete roof of a building with vertical cylindrical holes containing PCMs with the goal of reducing the heat flux from outdoors to the indoor space by increasing the thermal mass of the roof. A numerical model was validated though the experimental data and it allowed the effectiveness of the PCM in the roof to be demonstrated. Moreover, the simulations demonstrated that the heat gains could be reduced significantly with larger PCM hole diameters.

In recent years, other studies have been carried out to demonstrate how the application of phase change materials to the roof of buildings contributes to reducing the thermal loads and consequently the energy consumption of the building, especially during days with high solar radiation.

Boobalakrishnan et al. [19] conducted an experimental investigation to reduce the internal temperature of a single-story industrial building with a metal roof through the help of a PCM. A scale model of the proposed building was fabricated and tested. The test results showed that the PCM significantly reduced the roof temperature and consequently the indoor temperature. Quantitatively, the daily average internal temperature was lowered by $5{ }^{\circ} \mathrm{C}$ and the peak internal temperature was decreased by $9.5^{\circ} \mathrm{C}$ as a result of the application of the PCM.

Al-Yasiri et al. [20] investigated a PCM on a roof and found that the maximum interior surface temperature was reduced by up to $8.75^{\circ} \mathrm{C}$. On the basis of these results and findings, the authors stated that the application of a PCM to a roof could effectively reduce the heat transfer through the building components and contribute to building energy saving.

Thongtha et al. [21] focused their study on the application of a PCM combined with a fiber cement roofing sheet $\left(40^{\circ}\right.$ slope angle) to reduce heat transfer through a building. By composing four different configurations (two of which included a PCM), they observed an interior temperature reduction of $1.5^{\circ} \mathrm{C}$ (from $26.8^{\circ} \mathrm{C}$ to $25.3^{\circ} \mathrm{C}$ ) in the room where the PCM was added.

In most of the above-mentioned applications, the PCMs were incorporated through the microencapsulation technique. However, an easy integration of a PCM with building elements can also be obtained by means of the macro encapsulation technique [12]. Nevertheless, the adoption of metal or polymeric envelopes/cases for encapsulation purposes could lead to an alteration of the equivalent thermal properties of the PCM (e.g., a nonhomogeneous distribution of the PCM, air gaps, thermal bridges), if compared with the bulk PCM properties.

Until now, the main laboratory test used to measure the properties of PCM has been Differential Scanning Calorimetry (DSC), according to ASTM E793-06 [22], as indicated in the E793 and E967 standards. The properties assessed through this method are measured on small samples which, however, are not able to represent the full-scale element in an adequate way.

In addition to DSC, the T-History (Temperature-History) method is also used in laboratories to assess the bulk properties of PCMs. Although the latter technique allows the problem related to the small size of the sample (which is typical of DSC methods) to be overcome, it still has limitations and drawbacks. In fact, it works well for bulk materials, but it is not suitable for application to components. The PCM is macro encapsulated inside a structure that has a rather complex geometry, which can cause variations in shape/thickness from one point to another and the possible presence of air pockets [11].

For these reasons, a new measurement approach, based on the Dynamic Heat Flow Meter apparatus (DHFM), has recently been introduced and adopted in several research studies to assess the heat storage capacity and to analyze the dynamic behavior of macroencapsulated PCMs [23-27]. Through the adoption of the DHFM, it is possible to measure the equivalent thermal properties of a full-scale panel containing PCMs, in accordance with the ASTM C1784:2020 standard [28].

This paper presents the results of laboratory and in-field analyses that were performed on a series of macro encapsulated PCMs. The laboratory tests were aimed at assessing the equivalent thermal properties of PCMs with different nominal phase change temperatures 
encapsulated in the same envelope. An exhaustive and reliable thermal characterization of this configuration was achieved through these tests. Furthermore, to assess the impact of the application of PCMs to building components, two selected PCM panels were applied to a roof component in a parallel test room system and compared with a reference roof without any PCM. A monitoring campaign was carried out to identify the thermal performance of this system under actual operating conditions and to assess the achievable benefits, in terms of temperature peak shifting and shaving and reduction in the heat gains. Finally, from the laboratory characterization results and from the application monitoring experience, some design guidelines were drawn up to maximize the exploitation of the PCM latent heat storage capacity.

\section{Materials and Methods}

\subsection{Laboratory Analysis}

The laboratory tests were aimed at assessing the equivalent thermal properties (thermal conductivity, specific enthalpy, and heat capacity), under steady-state and dynamic conditions. The tests were carried out on a commercial macro-encapsulated inorganic PCM product with three nominal melting temperature alternatives.

\subsubsection{Materials and Instrument}

The PCM panels selected for the laboratory testing are commercially available products named "Infinite $\mathrm{R}^{\mathrm{TM}}$ ", which are produced by "Insolcorp, LLC" [29]. The encapsulation envelope is based on polymeric films shaped into small bags $\left(50 \times 100 \mathrm{~mm}^{2}\right)$ filled with inorganic PCM (Figure 1a). The panels have an area that is easily adjustable by just cutting between the PCM bags. Three different samples, characterized by the same envelope but with different nominal phase change temperature PCMs, were tested (Table 1):

- Infinite $\mathrm{R}^{\mathrm{TM}} 21$ (sample $\mathrm{X}$ ), characterized by a phase change temperature of $\sim 21^{\circ} \mathrm{C}$

- Infinite $\mathrm{R}^{\mathrm{TM}} 23$ (sample $\mathrm{Y}$ ), characterized by a phase change temperature of $\sim 23^{\circ} \mathrm{C}$

- Infinite $\mathrm{R}^{\mathrm{TM}} 25$ (sample $\mathrm{Z}$ ), characterized by a phase change temperature of $\sim 25^{\circ} \mathrm{C}$

Table 1. Main characteristics of the Infinite $\mathrm{R}^{\mathrm{TM}}$ samples.

\begin{tabular}{ccc}
\hline & Value & Unit \\
\hline Size & $555 \times 546$ & {$\left[\mathrm{~mm}^{2}\right]$} \\
Thickness (s) & $\sim 6.9$ & {$[\mathrm{~mm}]$} \\
Weight (M) & $\sim 1.45$ & {$[\mathrm{~kg}]$} \\
Surface Mass (SM) & $\sim 4.8$ & {$\left[\mathrm{~kg} / \mathrm{m}^{2}\right]$} \\
Volume (V) & $\sim 2091$ & {$\left[\mathrm{~cm}^{3}\right]$} \\
Nominal melting temperature & $21(\mathrm{X}), 23(\mathrm{Y}), 25(\mathrm{Z})$ & {$\left[{ }^{\circ} \mathrm{C}\right]$} \\
\hline
\end{tabular}

The laboratory tests were carried out by adopting a Dynamic Heat Flux Meter (DHFM) FOX 600, (Figure 1c). The instrument can perform both steady state and dynamic thermal tests that allow different thermal properties to be measured to fully characterize the different samples in terms of:

- Equivalent thermal conductivity (solid and liquid phase)

- Heat capacity

- Enthalpy variation as a function of temperature

- Latent heat capacity 


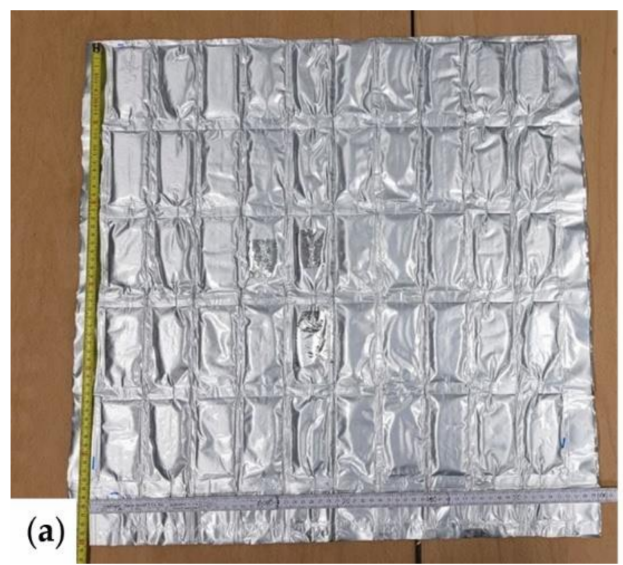

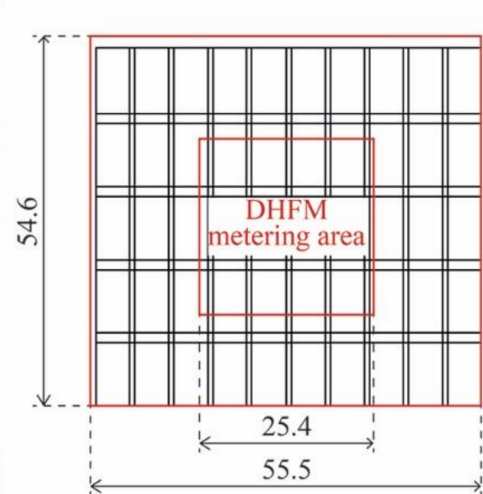

(b)

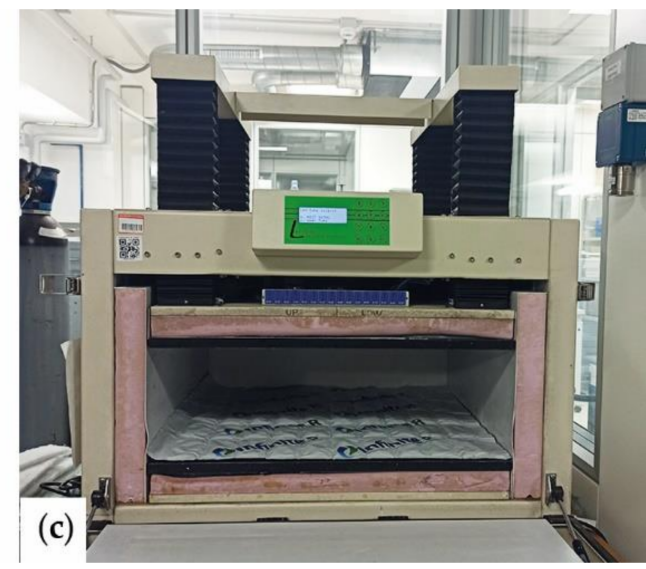

Figure 1. (a) The Infinite $\mathrm{R}^{\mathrm{TM}}$ panel; (b) Sample dimension and metering area; (c) The DHFM apparatus.

\subsubsection{Measured Thermal Properties}

The equivalent thermal conductivity $\left(\lambda_{\text {eq }}\right)$ was measured according to the EN 12664:2001 standard [30]. The final value was calculated according to Equation (1).

$$
\lambda_{e q}=\frac{q \cdot s}{\Delta T}\left[\frac{W}{m K}\right]
$$

where: $s[\mathrm{~m}]$ is the sample thickness, $\Delta T[\mathrm{~K}]$ is the temperature difference between plates, $q$ $\left[\mathrm{W} / \mathrm{m}^{2}\right]$ is the specific measured heat flux.

The tests were performed using different set-point temperatures to determine the equivalent thermal conductivity of the samples with PCM in both a solid and liquid state. Moreover, tests were carried out with downward and upward heat fluxes to assess the influence of the heat flux direction. A summary of the different set-points adopted during the tests is shown in Table 2.

Table 2. Set-point temperatures used for the $X, Y$ and $Z$ samples.

\begin{tabular}{|c|c|c|c|c|c|c|}
\hline PCM Type & Test & Heat Flux Direction & $\mathbf{T}_{\text {up }}\left[{ }^{\circ} \mathbf{C}\right]$ & $\mathrm{T}_{\text {low }}\left[{ }^{\circ} \mathrm{C}\right]$ & $\Delta \mathrm{T}\left[{ }^{\circ} \mathrm{C}\right]$ & $\mathrm{T}_{\text {average }}\left[{ }^{\circ} \mathrm{C}\right]$ \\
\hline \multirow{4}{*}{$X$} & \multirow{2}{*}{ Test 1 (solid) } & upward & 10 & 20 & 10 & 15 \\
\hline & & downward & 20 & 10 & 10 & 15 \\
\hline & \multirow{2}{*}{ Test 2 (liquid) } & upward & 26 & 36 & 10 & 31 \\
\hline & & downward & 36 & 26 & 10 & 31 \\
\hline \multirow{4}{*}{ Y } & \multirow{2}{*}{ Test 1 (solid) } & upward & 14 & 24 & 10 & 19 \\
\hline & & downward & 24 & 14 & 10 & 19 \\
\hline & \multirow{2}{*}{ Test 2 (liquid) } & upward & 30 & 40 & 10 & 35 \\
\hline & & downward & 40 & 30 & 10 & 35 \\
\hline \multirow{4}{*}{ Z } & \multirow{2}{*}{ Test 1 (solid) } & upward & 14 & 24 & 10 & 19 \\
\hline & & downward & 24 & 14 & 10 & 19 \\
\hline & \multirow{2}{*}{ Test 2 (liquid) } & upward & 30 & 40 & 10 & 35 \\
\hline & & downward & 40 & 30 & 10 & 35 \\
\hline
\end{tabular}

A key-property that should be considered to assess the energy storage feature of a PCM is the enthalpy variation as a function of temperature over its phase change range. A series of measurements was conducted by repeatedly increasing the temperature (in $1 \mathrm{~K}$ steps) to perform this test through a dynamic heat flow meter device (ASTM C1784:2020 [28]). The setpoint temperatures for each test performed are shown in Table 3. The cumulative amount of energy that entered the specimen was recorded, starting from the time of the temperature change until a steady state was achieved. 
Table 3. The set-point temperatures (T) used to assess the enthalpy function for samples $\mathrm{X}, \mathrm{Y}$, and Z.

\begin{tabular}{ccccccccc}
\hline \multirow{2}{*}{ PCM Type } & \multirow{2}{*}{ Test } & \multirow{2}{*}{$\begin{array}{c}\text { Number of Set } \\
\text { Points }\end{array}$} & \multicolumn{2}{c}{ Initial } & \multicolumn{2}{c}{ Final } & \multicolumn{2}{c}{$\mathbf{T}_{\text {average }}\left[{ }^{\circ} \mathbf{C}\right]$} \\
\cline { 4 - 9 } & & & $\mathbf{T}_{\mathbf{1}}\left[{ }^{\circ} \mathbf{C}\right]$ & $\mathbf{T}_{\mathbf{2}}\left[{ }^{\circ} \mathbf{C}\right]$ & $\mathbf{T}_{\mathbf{1}}\left[{ }^{\circ} \mathbf{C}\right]$ & $\mathbf{T}_{\mathbf{2}}\left[{ }^{\circ} \mathbf{C}\right]$ & Initial & Final \\
\hline \multirow{2}{*}{$\mathrm{X}$} & Melting & 17 & 15.5 & 16.5 & 31.5 & 32.5 & 16 \\
& Solidification & 17 & 32.5 & 31.5 & 16.5 & 15.5 & 32 & 16 \\
\hline \multirow{2}{*}{$\mathrm{Y}$} & Melting & 17 & 15.5 & 16.5 & 31.5 & 32.5 & 16 & 32 \\
& Solidification & 17 & 32.5 & 31.5 & 16.5 & 15.5 & 32 & 16 \\
\hline \multirow{2}{*}{$\mathrm{C}$} & Melting & 17 & 15.5 & 16.5 & 31.5 & 32.5 & 32 \\
& Solidification & 17 & 32.5 & 31.5 & 16.5 & 15.5 & 32 & 16 \\
\hline
\end{tabular}

A preliminary conditioning was performed, through the DHFM, to ensure that the samples were in either a completely solid or liquid state (depending on the test). The samples were conditioned, for $1 \mathrm{~h}$, at constant temperature of:

- $7.5^{\circ} \mathrm{C}$ before the melting test (heating test)

- $40^{\circ} \mathrm{C}$ before the solidification test (cooling test)

The areal enthalpy, $h_{A}\left[\mathrm{~kJ} / \mathrm{m}^{2}\right]$, was determined according to the ASTM C1784:2020 standard [28]. These values were calculated as a sum of the single enthalpy values measured for each set-point, $h_{n}(1 \mathrm{~K})$, used for the enthalpy vs the temperature test (Equation (2)):

$$
h_{A}=\sum_{n=1}^{17} h_{n}(1 K)\left[\frac{k J}{m^{2}}\right]
$$

The areal latent enthalpy, $h_{A, l a t}$, was calculated according to Equation (3):

$$
h_{A, l a t}=h_{A}-h_{A, \text { sens }}\left[\frac{K J}{m^{2}}\right]
$$

where: $h_{A, \text { sens }}\left[\mathrm{kJ} / \mathrm{m}^{2}\right]$ is the areal sensible enthalpy determined according to Equation (4):

$$
h_{A, \text { sens }}=\frac{c_{p F, A}+c_{p M, A}}{2} \cdot \Delta T\left[\frac{k J}{m^{2}}\right]
$$

where: $c_{p F, A}\left(\mathrm{~kJ} / \mathrm{m}^{2} \mathrm{~K}\right)$ is the areal specific heat of the solidified PCM measured over the $15.5-16.5^{\circ} \mathrm{C}$ range; $c_{p M, A}\left(\mathrm{~kJ} / \mathrm{m}^{2} \mathrm{~K}\right)$ is the areal specific heat of the melted PCM measured over the $31.5-32.5^{\circ} \mathrm{C}$ range; $\Delta T$ is the total temperature variation of the test $\left(17^{\circ} \mathrm{C}\right.$ in this specific case).

\subsection{In-Field Test Room Analysis}

The in-field monitoring analysis was aimed at assessing the benefits achievable through the application of the PCM to roof components. The measurements were carried out on different roofing layouts (with and without a PCM layer) to compare the surface temperature, the heat fluxes, and the indoor room temperature conditions. In consideration of the expected temperatures of the monitoring season (autumn), only PCM Infinite $\mathrm{R}^{\mathrm{TM}} 21$ and Infinite $\mathrm{R}^{\mathrm{TM}} 23$ were used.

\subsubsection{Experimental Set-Up}

The monitoring campaign was carried out in three identical test cells (Figure 2), named TRIS (Testing Roofing Innovative Systems), located in the north of Italy (San Francesco al Campo, Turin). The cells were specifically built to assess and compare the thermal performance of different roof layouts by monitoring various parameters (temperature and heat fluxes). The monitoring campaign was carried out in October 2020 for about two non-consecutive weeks. 


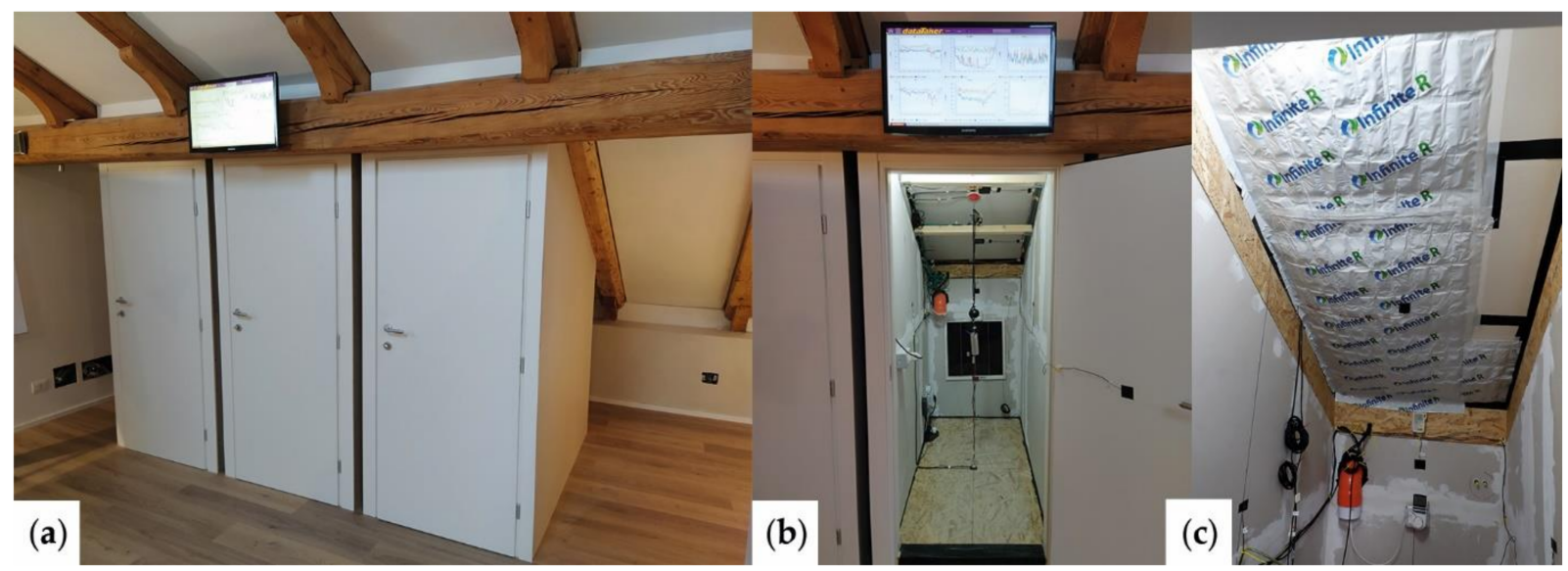

Figure 2. (a) The TRIS apparatus; (b) View of the internal space of a cell; (c) Installation of the Infinite $\mathrm{R}^{\mathrm{TM}}$ panels.

Three different layouts of the rooftop, characterized by the same dimensions, were installed in each test cell, and were equipped with a set of sensors to fully assess the thermal behaviour of each roof configuration.

The three monitored configurations were:

- Cell A: Reference without any PCM

- Cell B: PCM Infinite $\mathrm{R}^{\mathrm{TM}} 23$ (PCM Type " $\mathrm{Y}^{\prime \prime}$ )

- Cell C: PCM Infinite $\mathrm{R}^{\mathrm{TM}} 21$ (PCM Type " $\mathrm{X}^{\prime \prime}$ )

Details of the different layers of each roof in the test cells are given in Table 4.

Table 4. Layout of the monitored TRIS rooftop.

\begin{tabular}{|c|c|c|c|c|}
\hline & Material & Cell A & Cell B & Cell C \\
\hline 1 & Clay tiles & $30 \mathrm{~mm}$ & $30 \mathrm{~mm}$ & $30 \mathrm{~mm}$ \\
\hline 2 & Slightly ventilated air cavity & $70 \mathrm{~mm}$ & $70 \mathrm{~mm}$ & $70 \mathrm{~mm}$ \\
\hline 3 & Extruded Polystyrene (XPS) & $50 \mathrm{~mm}$ & $50 \mathrm{~mm}$ & $50 \mathrm{~mm}$ \\
\hline 4 & PCM & no PCM & $\begin{array}{l}\sim 7 \text { mm (Infinite } \mathrm{R}^{\mathrm{TM}} 23, \\
\text { PCM Type“ } \mathrm{Y}^{\prime \prime} \text { ) }\end{array}$ & $\begin{array}{c}\sim 7 \text { mm (Infinite } \mathrm{R}^{\mathrm{TM}} 21, \\
\text { PCM Type " } \mathrm{X}^{\prime} \text { ) }\end{array}$ \\
\hline 5 & Gypsum board & $12.5 \mathrm{~mm}$ & $12.5 \mathrm{~mm}$ & $12.5 \mathrm{~mm}$ \\
\hline
\end{tabular}

The outdoor boundary conditions were measured by a weather station and by two pyranometer sensors (Hukseflux LP02) for the incident (sloped) and horizontal global solar radiation (Figure 3a). Type-T thermocouples were installed in the test rooms to monitor the internal air temperature and the temperature of each interior surface. In addition, several thermocouples were installed in the interface between the roof layers (Figure $4 \mathrm{~b}$ ). Moreover, heat flux sensors (Hukseflux HFP01) were placed on the internal side of the panels to assess and compare the heat gains and losses for the three monitored configurations (Figure 3b). The sensors were connected to a data-logging system (Datataker DT85 with a CEM channel expansion module) which collected data at a timestep of $15 \mathrm{~min}$. The collected data were analyzed, and a comparison between rooms A, B and C was performed to assess the impact of the PCM on the temperatures and heat fluxes. The names of the sensors are shown in Figure 4a. 


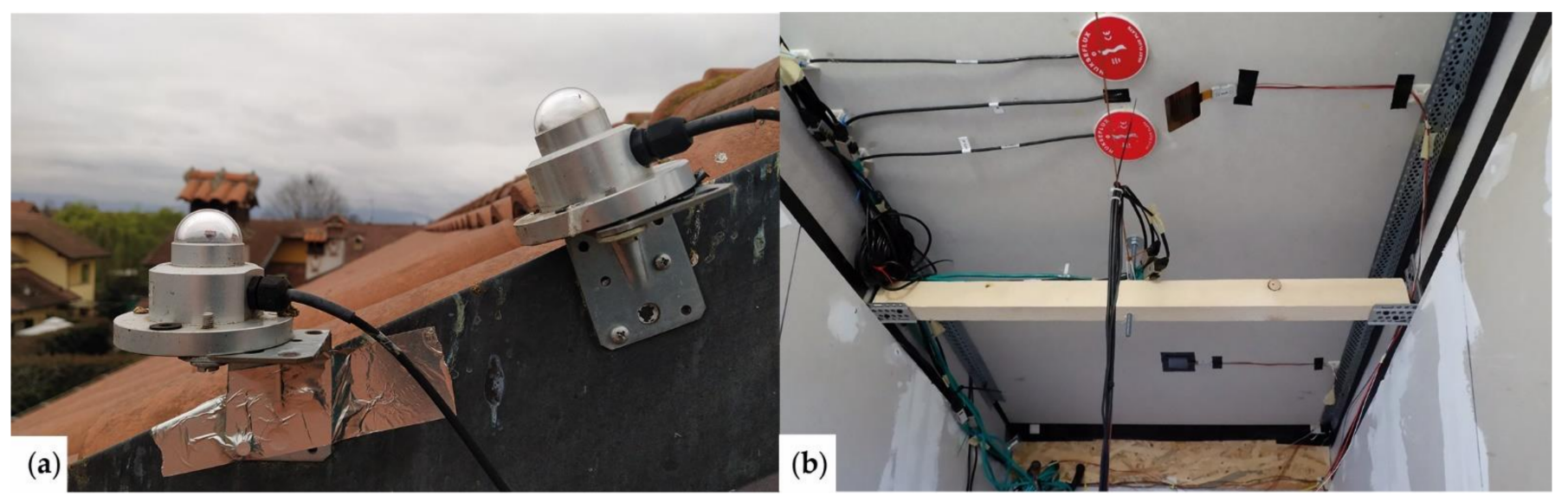

Figure 3. (a) The external pyranometer sensors; (b) Picture of the sensors located in the interface of the rooftop panel.
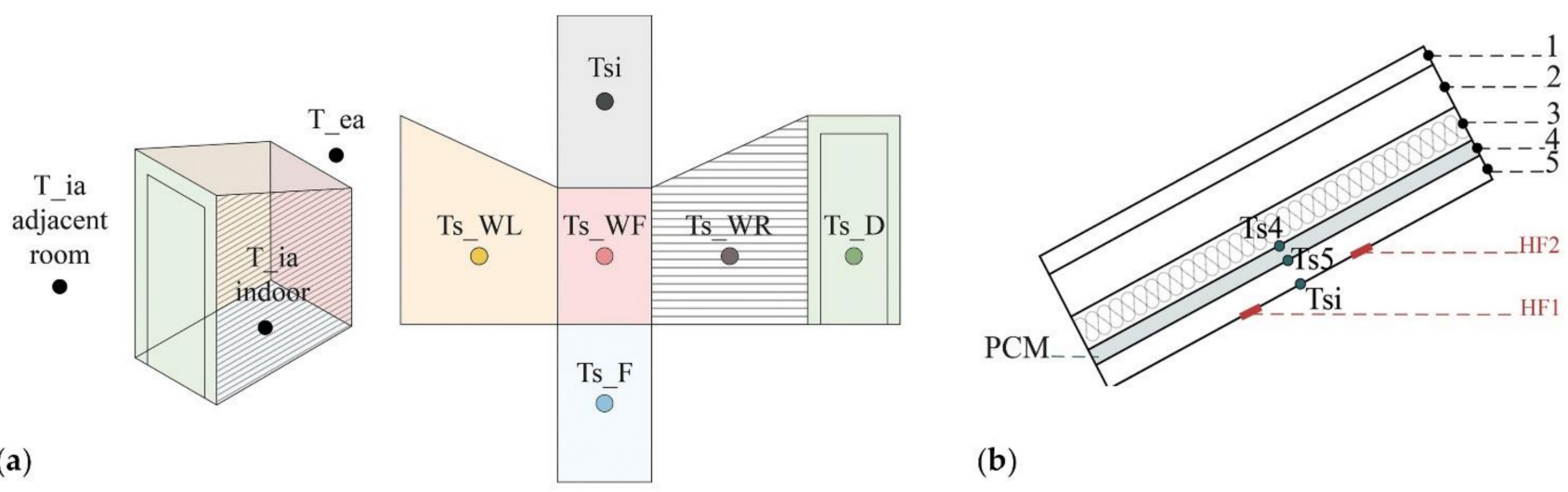

(b)

Figure 4. (a) Scheme of the sensors installed in the test cells for the measurement of the indoor/outdoor air temperatures (on the left) and the surface temperature of all the surfaces surrounding the indoor environment (on the right); (b) Cross section of the roof.

From the collected data, it was possible to compare different parameters:

- The internal surface temperature, measured by means of the thermocouples (Tsi)

- The heat fluxes, calculated as the mean value between the two heat flux sensor plates installed on the internal side of the roof (HF1, HF2)

- The temperatures reached by the PCM layer, calculated as the average between the two-thermocouples on the upper and the lower sides of the layer (Ts4, Ts5)

- The mean radiant temperature $\left(\mathrm{T}_{\mathrm{mr}}\right)$ of a sphere in the center of the indoor environment, calculated using (Equation (5)):

$$
\mathrm{T}_{\mathrm{mr}}=\sqrt[4]{\sum_{i=1}^{j} F_{i j} \times T s_{i j}^{4}}[K]
$$

where: $F_{i j}$ are the geometrical view factors (shown in Table 5) and $T s_{i j}[K]$ are the surface temperatures (shown in Figure 4a) of all the surfaces surrounding the indoor environment $\left(T s_{-} F, T s_{-} W R, T s_{-} W L, T s_{-} W F, T s \_D, T s i\right)$. 
Table 5. The calculated view factors, $F_{i j}$.

\begin{tabular}{cc}
\hline Surface & View Factors [-] \\
\hline Wall-Left & 0.311 \\
Wall-Right & 0.311 \\
Wall-Front & 0.087 \\
Door & 0.108 \\
Floor & 0.087 \\
Ceiling & 0.096 \\
\hline
\end{tabular}

\subsubsection{Monitoring Period and Performed Tests}

The monitoring campaign was carried out in October 2020 over two non-consecutive weeks. Two different tests were carried out with different ventilation strategies under free-running conditions. Details of the different ventilation strategies are shown in Table 6:

- Test_1 (7-13 October): mechanical ventilation system switched ON from 7:00 am to 8:00 am. The air change rate $(\mathrm{ACH})$ was $\sim 4.5[\mathrm{~L} / \mathrm{h}]$. This condition was intended to simulate opening the windows during the morning to cool down the buildings through airing.

- Test_2 (16-21 October): ventilation OFF and just air infiltration with the outdoors (an airtight taping system was applied to minimize infiltration from the outdoor environment, therefore minimizing the $\mathrm{ACH}$ ).

Table 6. Summary of the two test conditions.

\begin{tabular}{cccc}
\hline & & Test_1 & Test_2 \\
\hline Period & - & $7-13$ October & 16-21 October \\
\hline Internal loads & [internal LED lamp 19 W] & ON (6:00-20:00) & ON (6:00-20:00) \\
\hline \multirow{2}{*}{ Ventilation } & Schedule & ON (7:00-8:00) & OFF (00:00-24:00) \\
\cline { 2 - 4 } & Ventilation rate $(\mathrm{ACH})$ & $\sim 4.5[\mathrm{~L} / \mathrm{h}]$ & - \\
\hline
\end{tabular}

\section{Results and Discussion}

3.1. Laboratory Test Results

3.1.1. Equivalent Thermal Conductivity

The equivalent thermal conductivities measured for the three different samples are summarized in Table 7.

Table 7. Equivalent thermal conductivity test results.

\begin{tabular}{|c|c|c|c|c|c|c|c|}
\hline PCM Type & Test & $\begin{array}{l}\text { Heat Flux } \\
\text { Direction }\end{array}$ & $\begin{array}{c}\mathrm{T}_{\text {up }} \\
{\left[{ }^{\circ} \mathrm{C}\right]}\end{array}$ & $\begin{array}{l}\mathrm{T}_{\text {low }} \\
{\left[{ }^{\circ} \mathrm{C}\right]} \\
\end{array}$ & $\begin{array}{l}\mathrm{T}_{\text {avg }} \\
{\left[{ }^{\circ} \mathrm{C}\right]}\end{array}$ & $\begin{array}{c}\lambda_{\text {eq }} \\
{[W / m K]}\end{array}$ & $\begin{array}{c}\lambda_{\text {eq_avg }} \\
{[\mathrm{W} / \mathrm{mK}]}\end{array}$ \\
\hline \multirow{4}{*}{$x$} & \multirow{2}{*}{ Test 1 (solid) } & upward & 10 & 20 & 15 & $0.176 \pm 0.004$ & \multirow{2}{*}{$0.176 \pm 0.004$} \\
\hline & & downward & 20 & 10 & 15 & $0.175 \pm 0.004$ & \\
\hline & \multirow{2}{*}{ Test 2 (liquid) } & upward & 26 & 36 & 31 & $0.186 \pm 0.005$ & \multirow{2}{*}{$0.186 \pm 0.005$} \\
\hline & & downward & 36 & 26 & 31 & $0.186 \pm 0.005$ & \\
\hline \multirow{4}{*}{ Y } & \multirow{2}{*}{ Test 1 (solid) } & upward & 14 & 24 & 19 & $0.221 \pm 0.005$ & \multirow{2}{*}{$0.220 \pm 0.005$} \\
\hline & & downward & 24 & 14 & 19 & $0.219 \pm 0.005$ & \\
\hline & \multirow{2}{*}{ Test 2 (liquid) } & upward & 30 & 40 & 35 & $0.209 \pm 0.005$ & \multirow{2}{*}{$0.209 \pm 0.005$} \\
\hline & & downward & 40 & 30 & 35 & $0.208 \pm 0.005$ & \\
\hline \multirow{4}{*}{ Z } & \multirow{2}{*}{ Test 1 (solid) } & upward & 14 & 24 & 19 & $0.153 \pm 0.008$ & \multirow{2}{*}{$0.150 \pm 0.008$} \\
\hline & & downward & 24 & 14 & 19 & $0.146 \pm 0.008$ & \\
\hline & \multirow{2}{*}{ Test 2 (liquid) } & upward & 30 & 40 & 35 & $0.191 \pm 0.012$ & \multirow{2}{*}{$0.193 \pm 0.012$} \\
\hline & & downward & 40 & 30 & 35 & $0.195 \pm 0.012$ & \\
\hline
\end{tabular}


Since a negligible difference was detected between the data measured during the tests with upward heat flux and those with downward heat flux, an average between the two data sets is provided ( $\left.\lambda_{\text {eq_avg }}\right)$. As it is possible to observe, the equivalent thermal conductivity of the three PCM samples ranges between $0.150 \mathrm{~W} / \mathrm{mK}$ (PCM Z solid) and $0.220 \mathrm{~W} / \mathrm{mK}$ (PCM Y solid).

The results show that the difference between the values measured in the liquid and solid-states is relatively small (about 5\%) for PCM X and PCM Y. Instead, it is worth mentioning that PCM Z, with a nominal melting temperature of $25^{\circ} \mathrm{C}$, shows a greater difference between the solid and the liquid states test (the liquid thermal conductivity is about $29 \%$ higher than the solid one).

Compared with literature data, all the measured thermal conductivity results were significantly lower than expected. A relatively higher thermal conductivity (in the $0.540-1.088 \mathrm{~W} / \mathrm{mK}$ range) is generally reported in literature for salt hydrate PCMs with melting temperatures close to the indoor temperature [9,31-33]. This difference can be explained by considering that the literature data were determined using the DSC method on bulk PCMs, while the thermal conductivity measured in this study is an equivalent value of the whole PCM sample (PCM and container), which is influenced to a great extent by the presence of air pockets and by the envelope material of the container.

\subsubsection{Enthalpy vs. Temperature}

The results of the enthalpy variation as a function of temperature are shown in Figure 5 for PCM X (Infinite $\mathrm{R}^{\mathrm{TM}} 21$ ), in Figure 6 for PCM Y (Infinite $\mathrm{R}^{\mathrm{TM}}$ 23) and in Figure 7 for PCM Z (Infinite $R^{\mathrm{TM}}$ 25). The curves relating to both the melting phase (gray line) and solidification phase (black line) are plotted in these graphs.
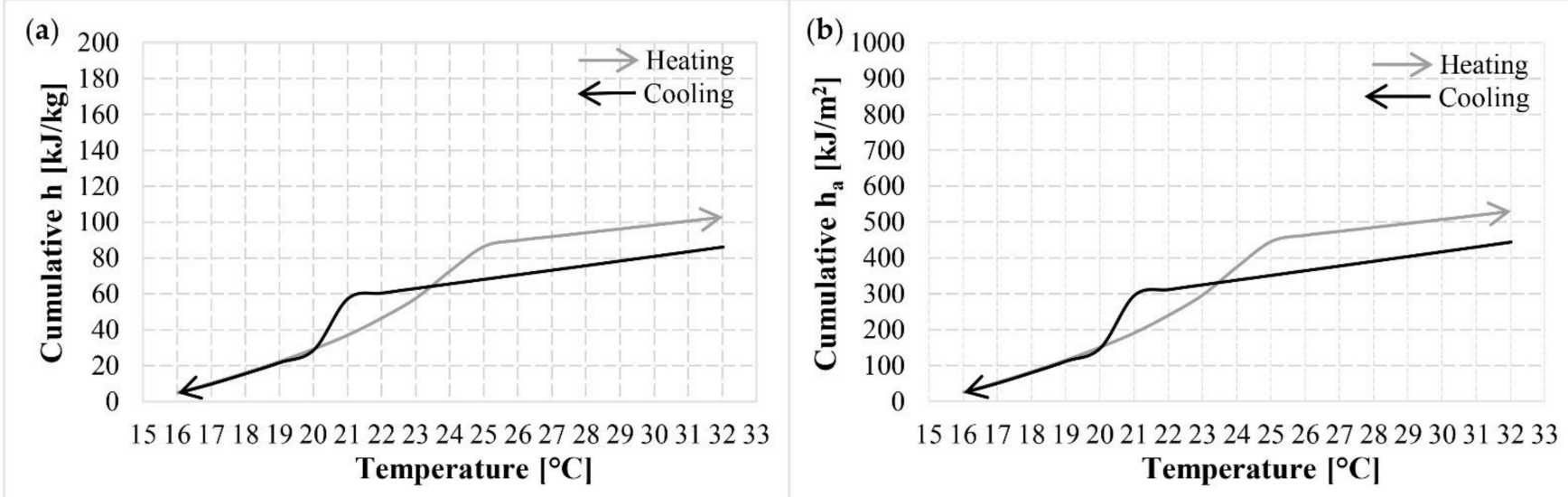

Figure 5. Enthalpy results: cumulative enthalpy (a) and areal cumulative enthalpy (b) of PCM X (Infinite $\mathrm{R}^{\mathrm{TM}}$ 21).

For the PCM X (Figure 5), it can be observed that:

- During the melting phase (gray line), the melting process starts at $\sim 19^{\circ} \mathrm{C}$, reaches its maximum value between $23^{\circ} \mathrm{C}$ and $25^{\circ} \mathrm{C}$ and ends at $25^{\circ} \mathrm{C}$.

- The solidification phase (black line) is concentrated over the $21-20^{\circ} \mathrm{C}$ range, thus corresponding to its partial enthalpy peak.

- The hysteresis phenomena are quite evident, with a difference of about $4{ }^{\circ} \mathrm{C}$ between the temperature at which the PCM is fully melted and the temperature at which solidification begins. 

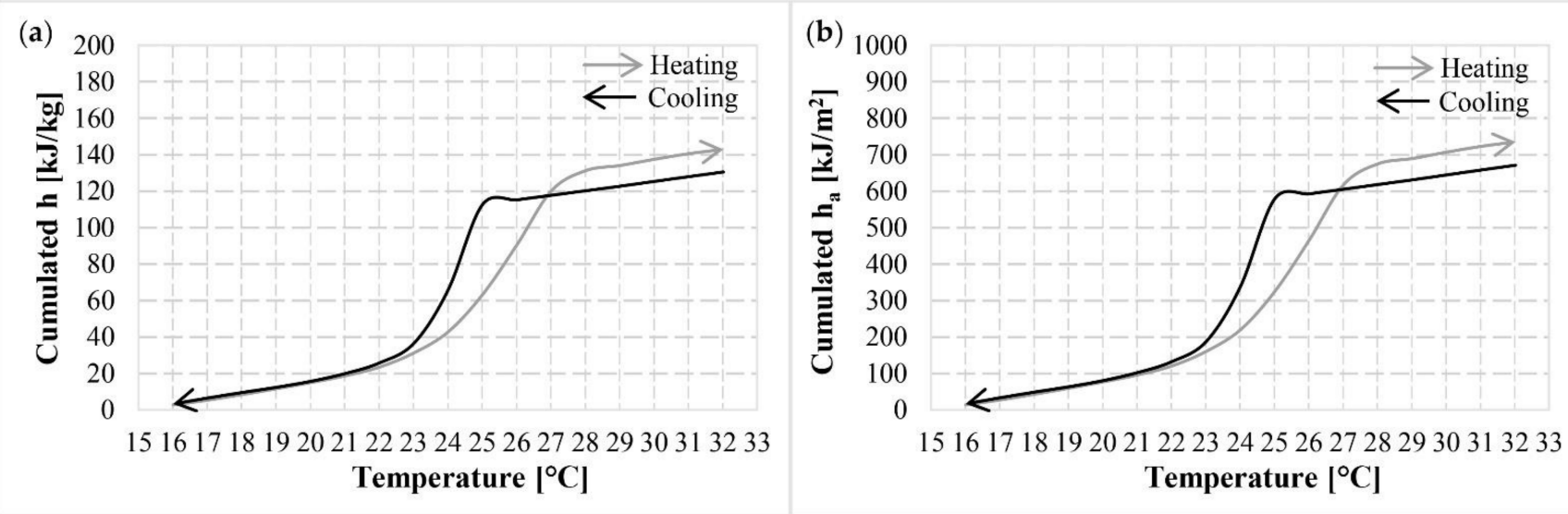

Figure 6. Enthalpy results: cumulative enthalpy (a) and areal cumulative enthalpy (b) of PCM Y (Infinite $\mathrm{R}^{\mathrm{TM}}$ 23).
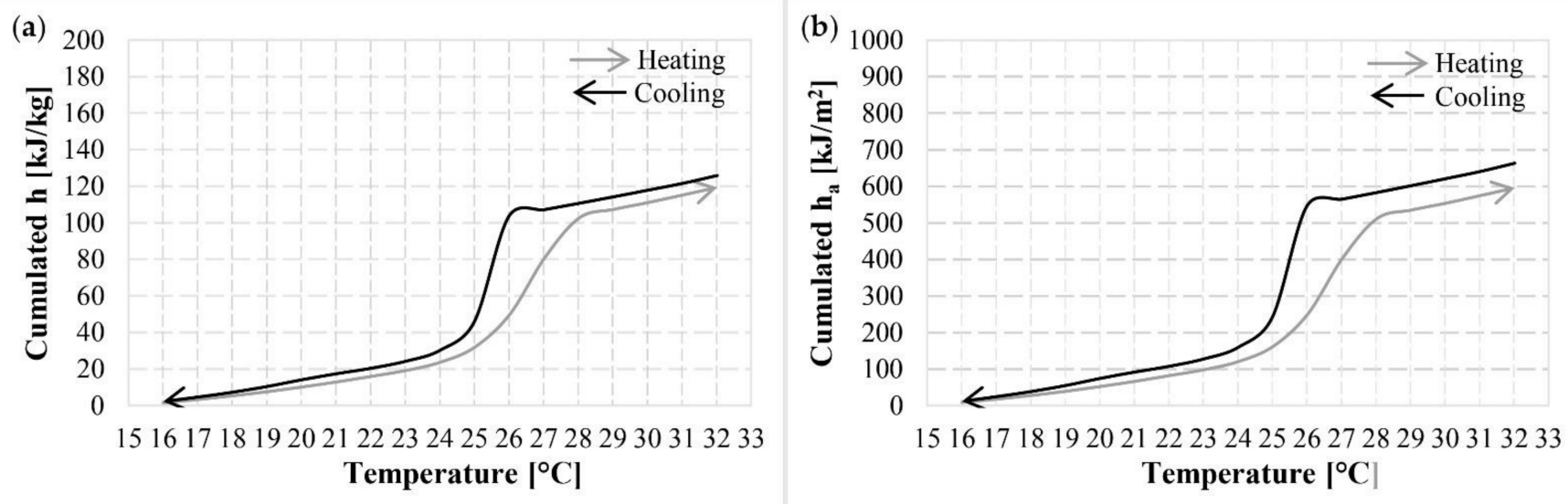

Figure 7. Enthalpy results: cumulative enthalpy (a) and areal cumulative enthalpy (b) of Sample Z (Infinite $\mathrm{R}^{\mathrm{TM}}$ 25).

The results of PCM Y (Figure 6) show that:

- $\quad$ During the melting phase (gray line), the melting process starts at $\sim 23^{\circ} \mathrm{C}$, reaches its maximum value between $24^{\circ} \mathrm{C}$ and $27^{\circ} \mathrm{C}$ and ends at $28^{\circ} \mathrm{C}$.

- The solidification phase (black line) is concentrated over the $25-23^{\circ} \mathrm{C}$ range, thus corresponding to its maximum enthalpy variation.

- The hysteresis phenomena are still quite evident with a difference of about $2.5^{\circ} \mathrm{C}$ between the temperature at which the PCM is fully melted $\left(\sim 27.5^{\circ} \mathrm{C}\right)$ and the temperature at which solidification begins $\left(\sim 25^{\circ} \mathrm{C}\right)$. However, the hysteresis is smaller than in the PCM X case.

From the results of PCM Z (Figure 7), it is possible to highlight that:

- During the melting phase (gray line), the transition starts at $24{ }^{\circ} \mathrm{C}$ and ends at $28{ }^{\circ} \mathrm{C}$, with the peak at $\sim 28^{\circ} \mathrm{C}$.

- During the solidification phase (black line), the transition phenomena start at $26{ }^{\circ} \mathrm{C}$ and end at $24{ }^{\circ} \mathrm{C}$.

- The hysteresis phenomena are quite evident with a difference of about $2{ }^{\circ} \mathrm{C}$ between the temperature at which the PCM is fully melted $\left(\sim 28^{\circ} \mathrm{C}\right)$ and the temperature at which solidification begins $\left(\sim 26^{\circ} \mathrm{C}\right)$.

The obtained values show that the behavior of PCM Y and PCM Z differ less than expected, considering their nominal temperatures of $23{ }^{\circ} \mathrm{C}$ and $25{ }^{\circ} \mathrm{C}$, respectively, as the phase transitions occur in the same temperature range for both. 
Furthermore, the results of these tests show that the melting and solidification enthalpy curves do not end at the same values, and that a variation of between $\sim 5-20 \%$ is observed. These results can be justified by considering the different velocities between the heating and the cooling tests. When adopting DHFM as the test device, the temperature velocity of the step variation cannot be fully controlled as in DSC methods, and the cooling tests are generally slower than the heating ones because of the different heating and cooling powers of the thermoelectric generator (Peltier cells). As highlighted in [34], an interlab test activity has demonstrated that different tests' velocities may influence the PCM storage capacity to a great extent.

\subsubsection{Equivalent Enthalpy and Latent Enthalpy}

The measurement results of the equivalent enthalpy, latent enthalpy, and areal enthalpy are summarized in (Table 8). The equivalent enthalpy $(\mathrm{h})$ and the areal enthalpy $\left(h_{A}\right)$ were calculated considering the sum of the partial enthalpies (or the maximum cumulated enthalpy values) that were determined over the $16-32{ }^{\circ} \mathrm{C}$ range.

Table 8. Equivalent heat capacity and latent heat capacity results.

\begin{tabular}{|c|c|c|c|c|c|c|c|}
\hline PCM Type & Test & Type & $\begin{array}{c}c_{p} \\
{[\mathrm{~kJ} / \mathrm{kgK}]}\end{array}$ & $\begin{array}{c}h_{A} \\
{\left[\mathrm{~kJ} / \mathrm{m}^{2}\right]}\end{array}$ & $\begin{array}{c}h_{A, l a t} \\
{\left[\mathrm{~kJ} / \mathrm{m}^{2}\right]}\end{array}$ & $\begin{array}{c}h \\
{[\mathrm{~kJ} / \mathrm{kg}]}\end{array}$ & $\begin{array}{c}h_{\text {,lat }} \\
{[\mathrm{kJ} / \mathrm{kg}]}\end{array}$ \\
\hline \multirow{2}{*}{$X$} & Test 1 & Melting test & 3.6 (melted) & 530 & 218 & 103 & 42 \\
\hline & Test 2 & Solidification test & 3.6 (solid) & 444 & 125 & 86 & 24 \\
\hline \multirow[b]{2}{*}{$\mathrm{Y}$} & Test 1 & Melting test & 2.5 (melted) & 735 & 514 & 143 & 100 \\
\hline & Test 2 & Solidification test & 2.9 (solid) & 671 & 419 & 131 & 81 \\
\hline \multirow{2}{*}{ Z } & Test 1 & Melting test & 2.9 (melted) & 596 & 341 & 119 & 71 \\
\hline & Test 2 & Solidification test & 3.3 (solid) & 663 & 369 & 126 & 70 \\
\hline
\end{tabular}

The specific heat $\left(c_{p}\right)$ was determined by considering the partial enthalpy values $(\mathrm{h})$ divided by the thermal gradient of $1 \mathrm{~K}$ (in this test) and measured in temperature steps of $\left(31.5-32.5^{\circ} \mathrm{C}\right)$ and $\left(15.5-16.5^{\circ} \mathrm{C}\right)$, in which it was assumed that the PCM conditions were fully liquid $\left(c_{p M}\right)$ or fully solid $\left(c_{p F}\right)$, respectively.

The obtained results show that the three analyzed PCMs have different storage properties:

- The maximum difference between the three PCMs is 39\% (melting test) and 51\% (solidification test).

- PCM X (PCM 21) shows the lowest latent enthalpy. This can be explained by considering that the PCM shows the lowest enthalpy $(\mathrm{h})$ and the highest specific heat $\left(c_{p}\right)$ in fully melted/fully solid PCMs, which is directly linked to the sensible heat capacity.

- PCM Y (PCM 23) and PCM Z (PCM 25) show similar heat capacity values. However, a significant difference in the latent enthalpy $\left(h_{\text {, lat }}\right)$ is observed (PCM Y shows a value that is about $51 \%$ higher than PCM Z).

As mentioned in the previous section, a difference of $\sim 8-16 \%$ is observed for the total enthalpy values between the melting and solidification tests. This, as previously mentioned, is caused by the non-complete control of the velocity of the temperature variation.

\subsection{In-Field Measurements Results}

\subsubsection{Boundary Conditions}

The boundary conditions (external and internal) of the two monitoring periods are plotted in Figure 8, while the solar radiation data are shown in Figure 9. The data acquired during the first monitoring period (Test_1) show an outdoor temperature of between $5{ }^{\circ} \mathrm{C}$ and $24^{\circ} \mathrm{C}$, with a maximum global incident solar radiation (Sol_I) of about $900 \mathrm{~W} / \mathrm{m}^{2}$. During the second monitoring period (Test_2), the outdoor conditions are characterized by lower external air temperatures $\left(6-18^{\circ} \mathrm{C}\right)$ and with some cloudy days (21 and 22 October). Regarding the internal air temperature of the test rooms surrounding environment (Tint), 
the values for Test $\_1$ are relatively stable around $\sim 21 \pm 1{ }^{\circ} \mathrm{C}$, and then decrease during Test_2 $\left(\sim 19^{\circ} \mathrm{C}\right)$.

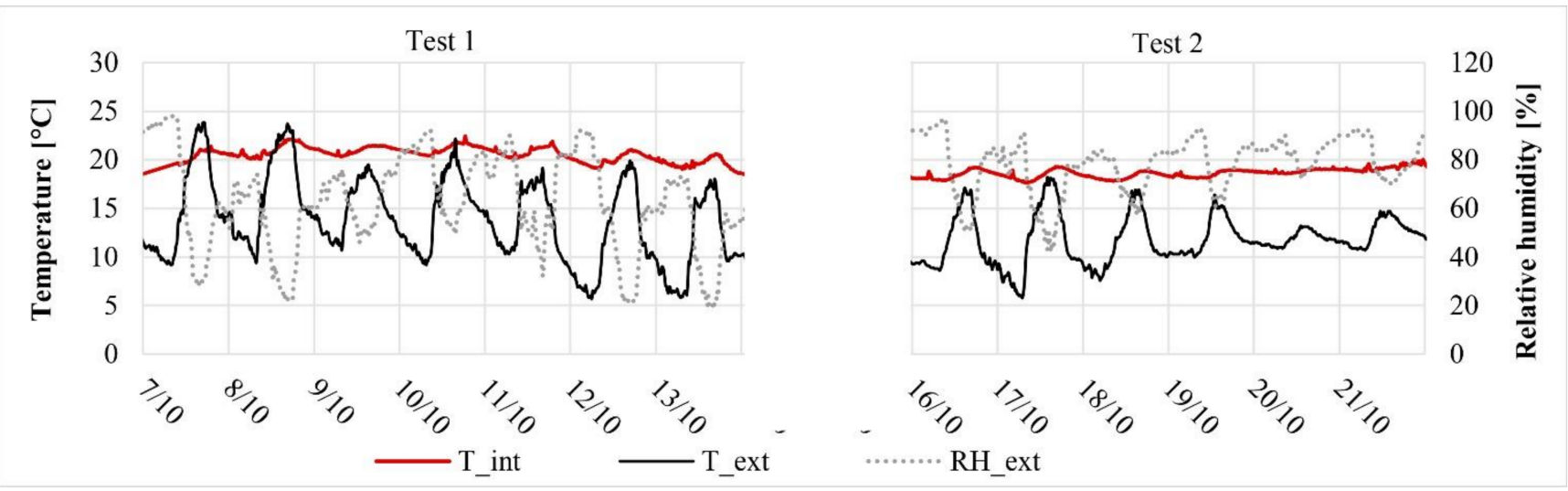

Figure 8. Boundary conditions: interior air temperature (T_int), external air temperature (T_ext), external relative humidity (RH_ext).
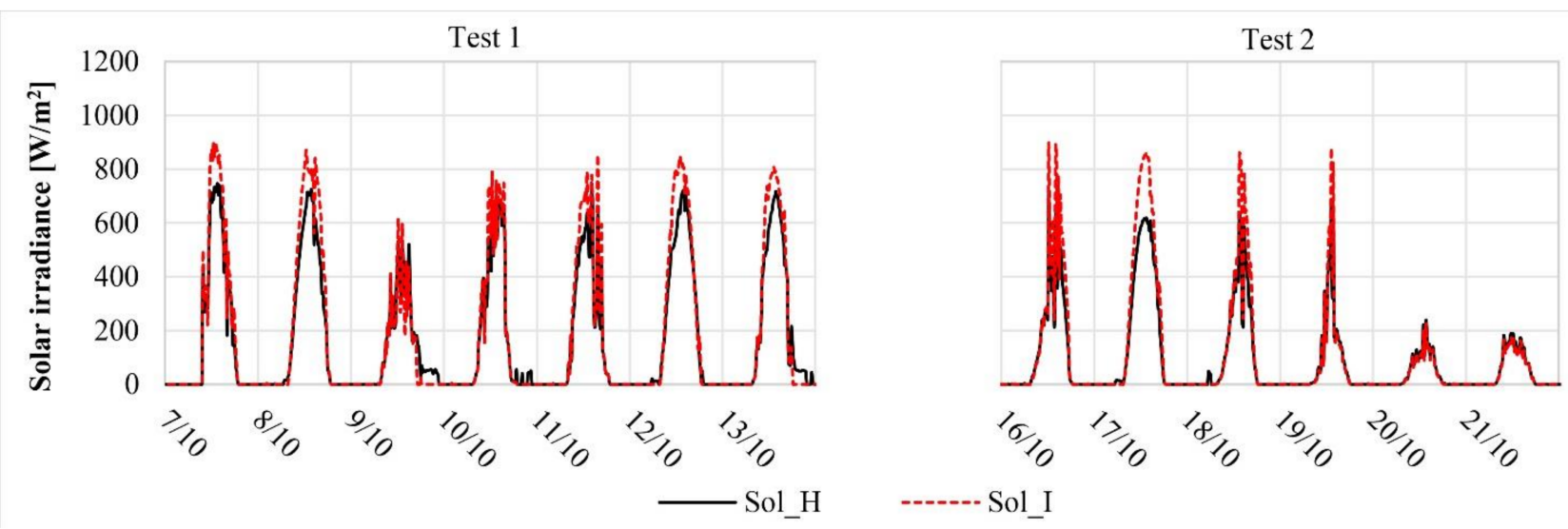

Figure 9. Boundary conditions: horizontal solar irradiance (Sol_H), incident global solar irradiance (Sol_I).

\subsubsection{Test_1}

Test_1, which involved the activation of ventilation (4.5 ACH from 7 am to $8 \mathrm{am}$ ), was carried out between 7 and 13 October. Moreover, the day characterized by the highest solar radiation and by the highest internal/external temperatures was selected for detailed analysis (8 October). The following data were analyzed:

- $\quad$ Surface temperatures (Ts)

- Heat flux (HF_m)

- $\quad$ PCM temperature (T_PCM)

- Mean radiant temperature $\left(\mathrm{T}_{\mathrm{mr}}\right)$

The monitored indoor surface temperature values of the roof are plotted in Figure 10a for the overall period. A reduction in the temperature peaks in Room B (PCM 23) and Room C (PCM 21), compared with the reference configuration (Room A), can easily be seen. Focusing the analysis on the reference day (Figure 10b), the maximum temperature reached in cell B (with Infinite $\mathrm{R}^{\mathrm{TM}} 23-\mathrm{PCM} \mathrm{Y}$ ) is $\sim 1.2^{\circ} \mathrm{C}$ lower than the maximum value achieved in cell $\mathrm{A}$ (from $23.6^{\circ} \mathrm{C}$ to $22.4^{\circ} \mathrm{C}$ ). A slightly more marked reduction of the temperature peak (about $1.5^{\circ} \mathrm{C}$ ) is achieved in Room C with Infinite $\mathrm{R}^{\mathrm{TM}} 21$ (from $23.6^{\circ} \mathrm{C}$ to $22.1^{\circ} \mathrm{C}$ ). 

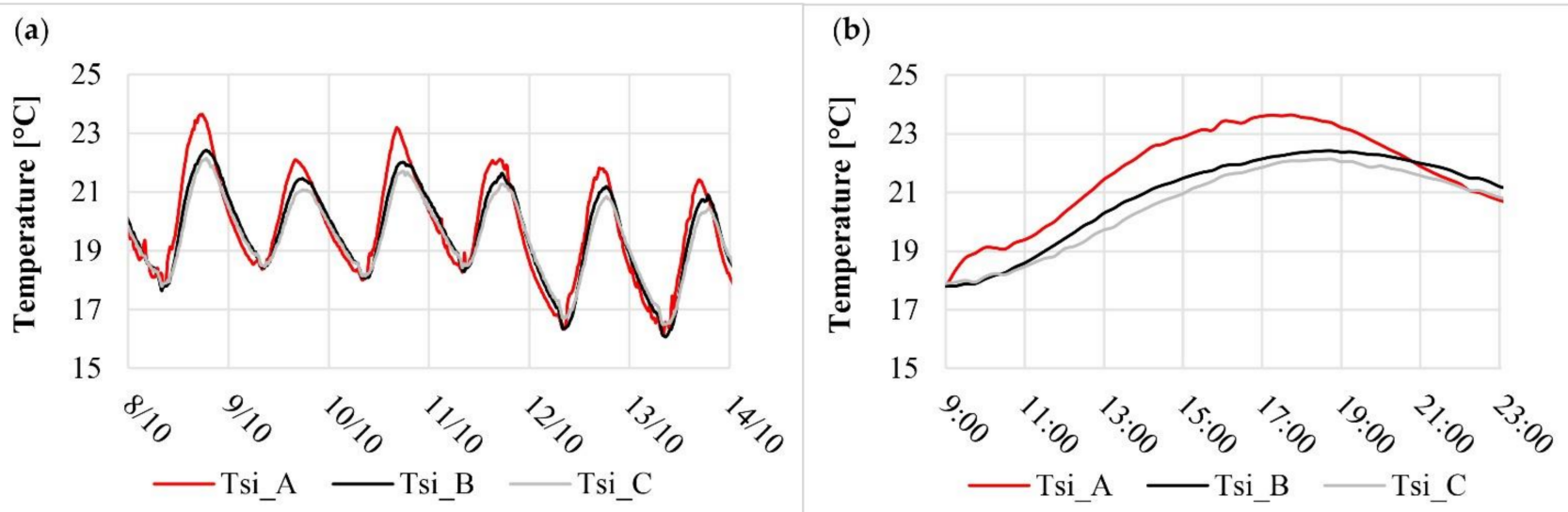

Figure 10. Internal surface temperature (Tsi) in the test rooms: (a) the whole period; (b) the reference day $(8 / 10)$.

Another consideration can be made by looking at the temperature values collected in the night hours (from 21:00 to 23:00). The surface temperatures in Rooms B and C were slightly higher than those reached in Room A (without any PCM layer); this phenomenon maybe related to the release of the heat stored in the PCM during the day, which is released during the night-time and early morning hours. Moreover, the presence of the PCM in the layers leads to a shift of the temperature peaks: in reference Room (A), the maximum temperature is reached at 18:00, while a delay of about 45-60 min is observed in Rooms B and C.

The heat flux analysis (Figure 11) shows a similar trend. The positive influence of the PCM can be observed during daytime, when a significant heat flux reduction (gains) occurs. A comparison of the data collected on the reference day (8 October) has revealed that:

- a heat flux reduction of $\sim 40 \%$ (from $9.4 \mathrm{~W} / \mathrm{m}^{2}$ to $5.6 \mathrm{~W} / \mathrm{m}^{2}$ ) can be achieved in the daily peak values, if Infinite $\mathrm{R}^{\mathrm{TM}} 23$ (PCM Y) is applied (Room B).

- a heat flux reduction of $\sim 48 \%$ (from $9.4 \mathrm{~W} / \mathrm{m}^{2}$ to $4.9 \mathrm{~W} / \mathrm{m}^{2}$ ) can be achieved in the daily peak values, if Infinite $\mathrm{R}^{\mathrm{TM}} 21$ (PCMX) is applied (Room C).

(a)

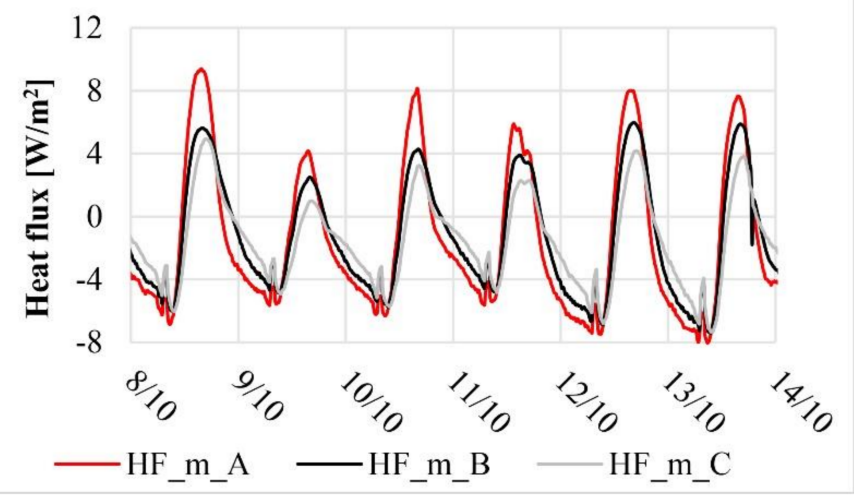

(b)

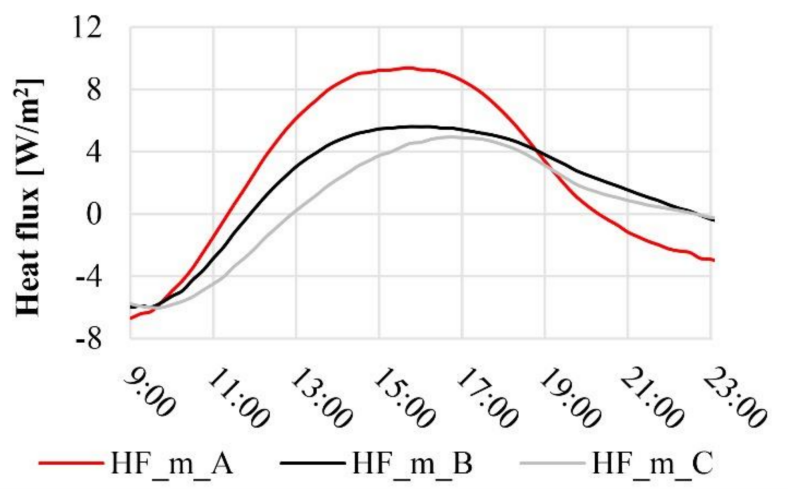

Figure 11. Monitored Heat fluxes (HF_m): (a) whole period; (b) the reference day $(8 / 10)$.

The temperatures of the PCM layer, shown in Figure 12, are the values collected from the sensors located in the upper and lower sides of the PCM panel (Ts4 and Ts5). 


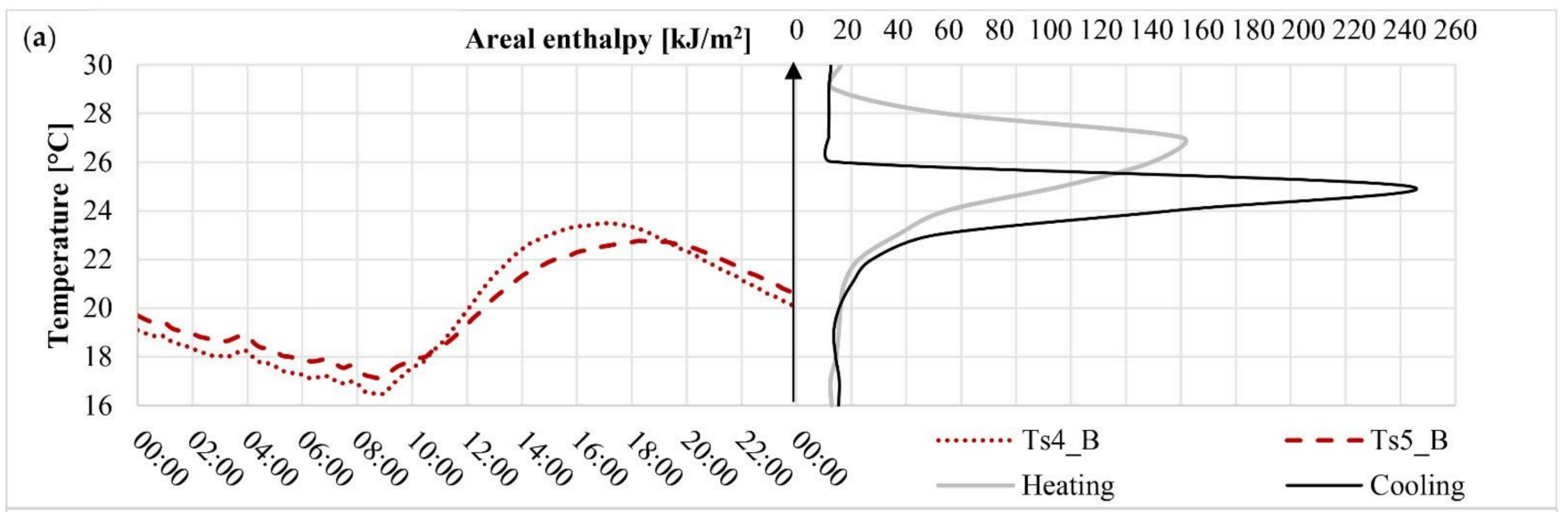

(b)

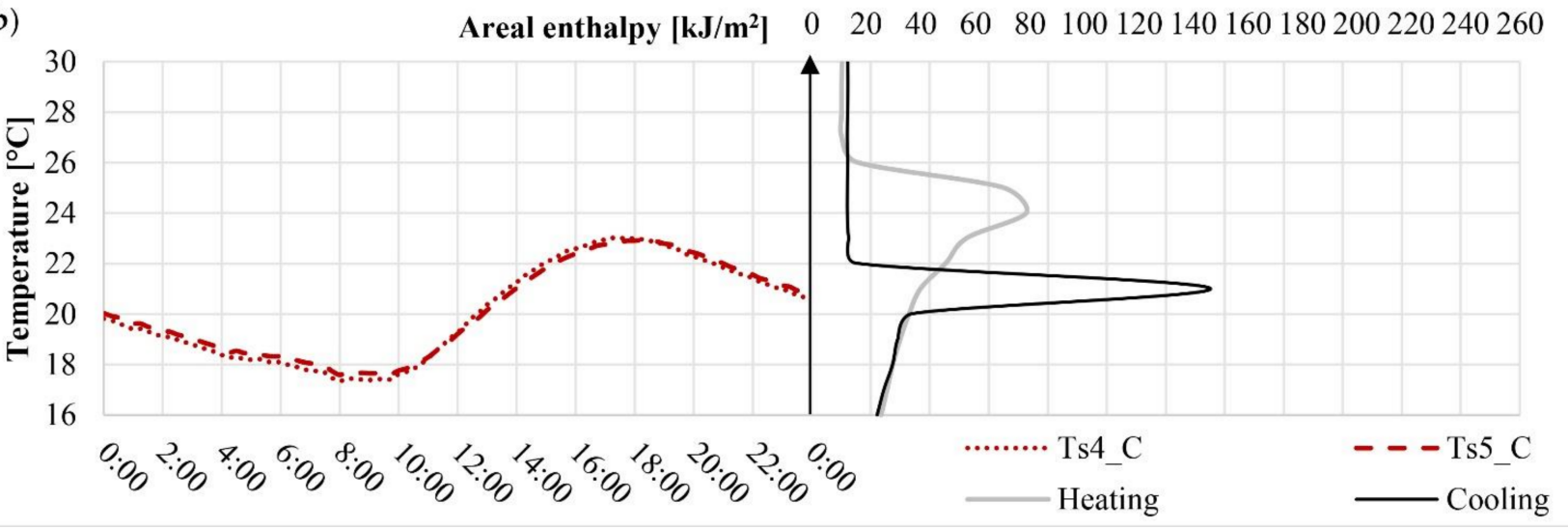

Figure 12. Monitored PCM temperatures: (a) PCM temperature of room B (reference day 8/10); (b) PCM temperature of room C (reference day $8 / 10$ ).

A comparison with the enthalpy vs. temperature values was carried out to assess the exploitation of the PCM latent heat storage capacity. A lower temperature variation was noticed in the cell equipped with the Infinite $R^{\mathrm{TM}} 21$ layer (cell C), while the Infinite $\mathrm{R}^{\mathrm{TM}}$ 23 (cell B) showed a higher temperature variation.

- Infinite $\mathrm{R}^{\mathrm{TM}} 23$ (Room B) showed a temperature variation of between $16.8{ }^{\circ} \mathrm{C}(8: 00)$ and $23{ }^{\circ} \mathrm{C}(16: 30)$, with an amplitude of $6.2^{\circ} \mathrm{C}$.

- Infinite $\mathrm{R}^{\mathrm{TM}} 21$ (Room $\mathrm{C}$ ) showed a temperature variation of between $18.2{ }^{\circ} \mathrm{C}(8: 00$ am) and $21.5^{\circ} \mathrm{C}(17: 00 \mathrm{pm})$, with an amplitude of $3.2^{\circ} \mathrm{C}$.

This behaviour is closely related to the different phase change temperatures of the two PCMs. Indeed, by comparing the PCM temperature profile (left) with the partial enthalpy plot (right), it is evident that PCM B (Infinite $\mathrm{R}^{\mathrm{TM}} 23$ ) only slightly exploits the latent heat capacity of the PCM during the heating phase and even less so in the cooling phase, while PCM C (Infinite $R^{\mathrm{TM}}$ 21) shows a higher exploitation of the latent heat capacity in both phases, and PCM_C (Infinite $\mathrm{R}^{\mathrm{TM}}$ 21) therefore operates in its mushy state for a longer period of time during the day.

The mean radiant temperature calculated for the three cells are shown in Figure 13. As expected, the benefits achieved, in terms of peak temperature reduction, when using the PCMs, are less evident. This is mainly due to the fact that the mean radiant temperature of the small test room is influenced to a great extent by all the other surrounding surfaces (floor, walls) rather than by the roof surface temperatures. 


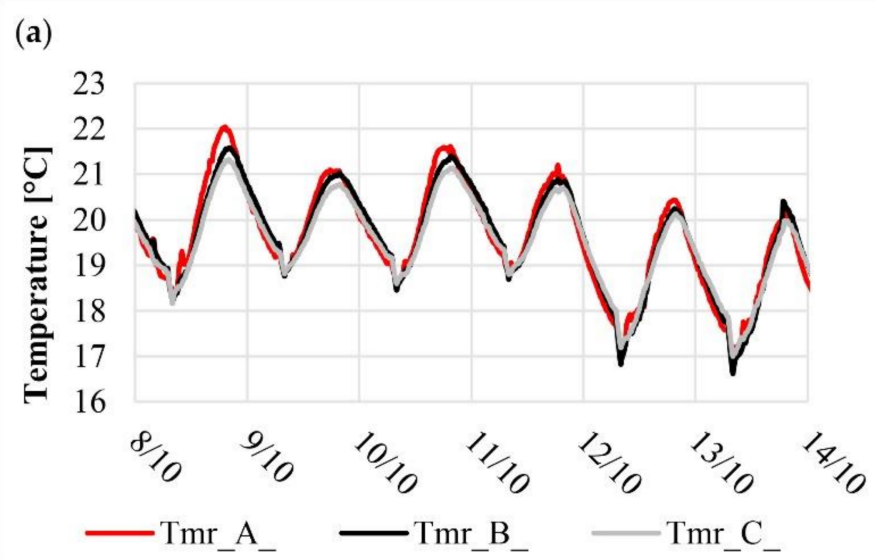

(b)

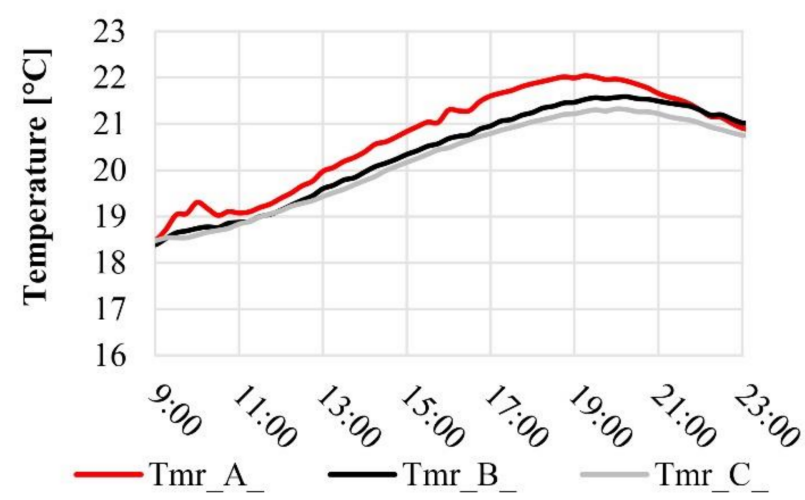

Figure 13. Calculated mean radiant temperature (Tmr): (a) whole period; (b) the reference day $(8 / 10)$.

Even though the influence of the PCM on the mean radiant temperature was limited, a reduction in the temperature variations can be seen. A reduction in the peak temperature of $\sim 0.7^{\circ} \mathrm{C}(\mathrm{C})$ can be observed for the reference day $(8 / 10)$ for cell $\mathrm{C}$, while a reduction of $\sim 0.5^{\circ} \mathrm{C}$ can be observed for cell $\mathrm{B}$.

\subsubsection{Test_2}

Test_2, without any mechanical ventilation, was carried out from 16 to 21 October. Moreover, the day characterized by the highest solar radiation and by the highest internal/external temperatures was selected for detailed analysis (17 October).

Coherently with Test_1, the following data were analyzed for the analysis of the monitored results:

- $\quad$ Surface temperatures (Ts)

- Heat flux (HF_m)

- $\quad$ PCM temperature (T_PCM)

- $\quad$ Mean radiant temperature $\left(\mathrm{T}_{\mathrm{mr}}\right)$

The monitored indoor surface temperature values of the roof are plotted in Figure 14a for the overall period. A reduction of the temperature peaks in Room B (PCM Y) and Room $\mathrm{C}(\mathrm{PCM} X)$, compared with the reference configuration (Room A), can be seen. Focusing the analysis on the reference day (Figure 14b), the maximum temperature reached in cell $\mathrm{B}$ (with Infinite $\mathrm{R}^{\mathrm{TM}}$ 23) was $\sim 0.6^{\circ} \mathrm{C}$ lower than the maximum value in cell A (from $21.1^{\circ} \mathrm{C}$ to $20.5^{\circ} \mathrm{C}$ ). A more evident reduction in the temperature peak (about $1.2{ }^{\circ} \mathrm{C}$ ) was observed in Room C, with Infinite $\mathrm{R}^{\mathrm{TM}} 21$ (from $21.1^{\circ} \mathrm{C}$ to $19.9^{\circ} \mathrm{C}$ ).
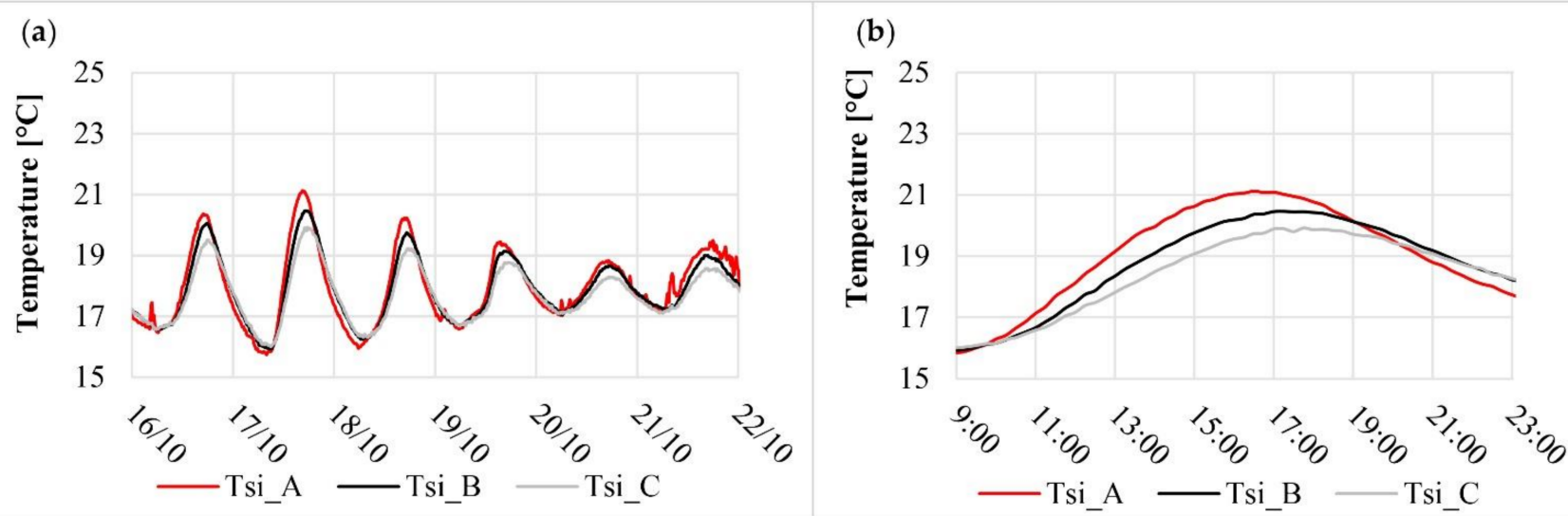

Figure 14. Surface temperature: (a) whole period; (b) the reference day $(17 / 10)$. 
Similarly to the Test \#1 analysis, the presence of the PCM in the layers led to a shift in the temperature peaks: the maximum temperature in reference room $(\mathrm{A})$ was reached at 18:00 while a delay of about 45-60 min was observed in Rooms B and C.

The heat flux results (Figure 15) confirm those of the temperature analysis.

(a)

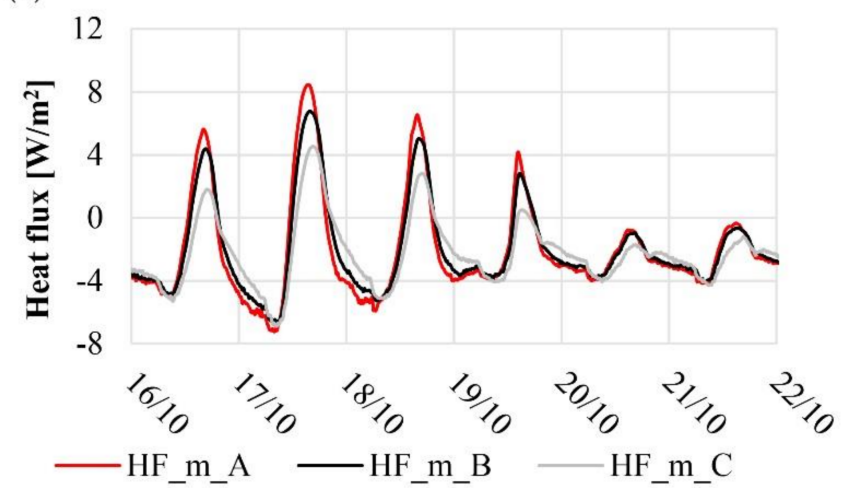

(b)

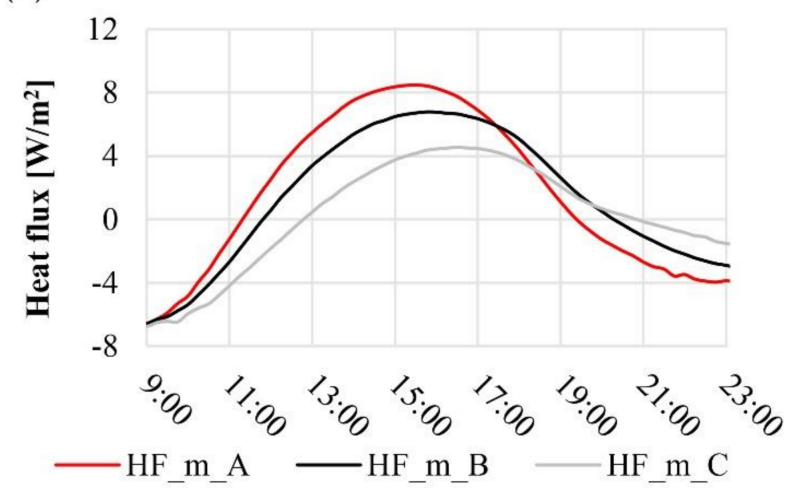

Figure 15. Monitored heat fluxes (HF_m): (a) whole period; (b) the reference day $(17 / 10)$.

A comparison of the data collected on the reference day (17 October) revealed that:

- a heat flux reduction of $\sim 20 \%$ (from $8.5 \mathrm{~W} / \mathrm{m}^{2}$ to $6.8 \mathrm{~W} / \mathrm{m}^{2}$ ) can be achieved in the daily peak values if Infinite $\mathrm{R}^{\mathrm{TM}} 23$ is applied (Room B).

- a heat flux reduction of $\sim 47 \%$ (from $8.5 \mathrm{~W} / \mathrm{m}^{2}$ to $4.5 \mathrm{~W} / \mathrm{m}^{2}$ ) can be achieved in the daily peak values if Infinite $\mathrm{R}^{\mathrm{TM}} 21$ is applied (Room C).

The PCM effect can be observed during daytime, when a significant heat flux reduction (gains) occurs for PCM X (similar to those observed in Test_1), while a lesser reduction of the heat fluxes $(\sim 20 \%)$ can be achieved with PCM Y

The temperatures of the PCM layers are plotted in Figure $16 \mathrm{a}, \mathrm{b}$ for Infinite $\mathrm{R}^{\mathrm{TM}} 23$ (Room B) and Infinite $\mathrm{R}^{\mathrm{TM}} 21$ (Room C), respectively. A comparison with the enthalpy vs. temperature values was carried out to assess the latent heat storage capacity exploitation of the PCMs. Similarly to Test \#1, a lower temperature variation can be noticed in the cell equipped with the Infinite $\mathrm{R}^{\mathrm{TM}} 21$ layer (cell C), while Infinite $\mathrm{R}^{\mathrm{TM}} 23$ (cell B) shows a higher temperature variation.

- Infinite $\mathrm{R}^{\mathrm{TM}} 23$ (Room B) shows a temperature variation of between $14.8^{\circ} \mathrm{C}(8: 00)$ and $21.4{ }^{\circ} \mathrm{C}(16: 30)$, with an amplitude of $6.6^{\circ} \mathrm{C}$.

- Infinite $\mathrm{R}^{\mathrm{TM}} 21$ (Room $\mathrm{C}$ ) shows a temperature variation of between $15.5^{\circ} \mathrm{C}(8: 00 \mathrm{am})$ and $20.7^{\circ} \mathrm{C}(17: 00 \mathrm{pm})$, with an amplitude of $5.2{ }^{\circ} \mathrm{C}$.

Compared with Test 1, both PCMs show a higher daily temperature variation. As it is possible to observe by combining the temperature trend with the partial enthalpy plot, both the PCMs operate without a good exploitation of the latent heat capacity. In the case of PCM Y (Infinite $\mathrm{R}^{\mathrm{TM}} 23$ ), it is worth underlining that it operates fully below the melting temperature. Therefore, the small peak temperature and heat flux reduction in Room $\mathrm{B}$, compared to Room A, depends mainly on the solid state sensible heat capacity of the PCM, which slightly increases the thermal inertia of the component.

If the mean radiant temperature is considered, the trends are in agreement with the surface temperature profiles. The influence of the PCM on the mean radiant temperature was very limited, a reduction of about $0.4{ }^{\circ} \mathrm{C}$ was observed for Room C (PCM 21), while PCM Y (PCM 23) in Room B reveals a negligible mean radiant temperature reduction $\left(\sim 0.1^{\circ} \mathrm{C}\right)$. Only a small delay in the peak values $(\sim 1 \mathrm{~h})$ can be remarked for both PCMs. 


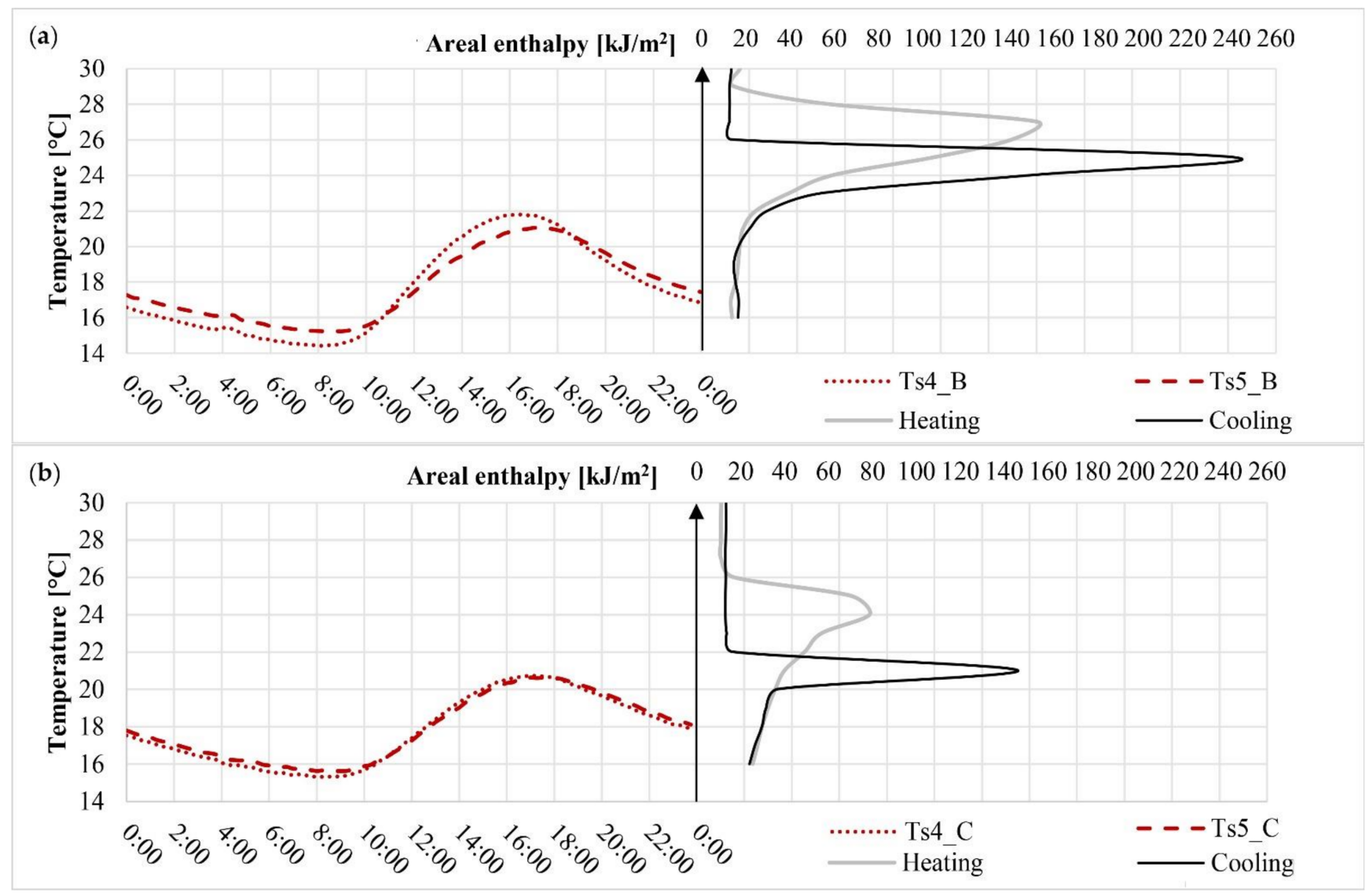

Figure 16. Monitored PCM temperatures: (a) PCM temperature of room B (the reference day 17/10); (b) PCM temperature of room C (the reference day $17 / 10$ ).

\section{Conclusions}

The present paper is aimed at assessing the thermal properties of macro encapsulated PCMs under conditions that are representative of the actual behaviour of the material when it is used in building components. Most of the information available in data sheets, such as the nominal melting temperatures and latent heat, are in fact typically measured on bulk materials and under laboratory conditions that are quite different from those to which the material is exposed in real buildings. Firstly, the measurements are conducted on small samples of the bulk materials. Such a configuration is far from being representative of macro encapsulated PCMs, since the bulk material is enclosed within containers which, apart from influencing the thermal properties of the ensemble, create air pockets and shape variations. The consequence is that the overall thermal properties are affected to a great extent. Secondly, the temperature variations during the tests are faster than the temperature time gradients that occur in a real environment.

In the present paper, two measurement methods have been proposed and investigated in order to overcome these glitches. One makes use of laboratory measurement apparatus, while the other resorts to a purposely-designed test cell.

More specifically, the equivalent thermal properties of macro encapsulated PCMs (Infinite $\left.\mathrm{R}^{\mathrm{TM}}\right)$, with different nominal phase change temperatures $\left(21,23\right.$, and $\left.25^{\circ} \mathrm{C}\right)$, were investigated under laboratory conditions and then applied to roof components. An experimental piece of apparatus, available at the Politecnico di Torino, called TRIS-Testing Roof Innovative System, was adopted for the latter test. Finally, the results of these tests were compared with the typical nominal values of the various materials available in data sheets.

A graphical representation of the measurement results, related to the change phase phenomena, has been proposed (see, e.g., Figures 12 and 16), that could help designers 
make an appropriate choice of the most suitable PCM (that is, determining the optimal range of phase change temperatures in relation to the envelope component temperatures).

The results of the laboratory characterization show similar equivalent thermal conductivity values for the three analyzed PCM samples, which range between 0.15 and $0.22 \mathrm{~W} / \mathrm{mK}$. These results clearly demonstrate that the equivalent thermal conductivity of a macro-encapsulated PCM might be quite different from the thermal conductivity of the bulk PCM typically reported in data sheets and literature (the literature values for salt hydrate PCMs are reported to be between 0.540 and $1.088 \mathrm{~W} / \mathrm{mK}[9,32,33])$.

As far as the results of enthalpy, as a function of temperature, are concerned, it is worth mentioning that a significant hysteresis phenomenon (from $2{ }^{\circ} \mathrm{C}$ to $4{ }^{\circ} \mathrm{C}$ ) was observed for all the PCMs. Moreover, the measured peak enthalpy of melting and solidification (average values) were slightly higher than the nominal melting/solidification values. It has emerged, from the laboratory results, that it is important to use equivalent properties of the macro-encapsulated PCMs for building energy modelling purposes.

Indeed, simplified simulation models require equivalent data, when a homogeneous PCM layer is assumed. Therefore, the use of data relative to the bulk PCM might not fully consider the complexity of the macro-encapsulation, which might lead to a significant alteration of the PCM behavior and of its melting/solidification processes.

The application and monitoring of two macro-encapsulated PCMs (Infinite RTM 21 and Infinite RTM 23) with different transition temperatures in a real roof component have allowed the benefits achievable, in terms of heat fluxes and temperature variation reduction, to be detected. Moreover, the effect of natural ventilation on the thermal performance of the component has been analyzed.

The first monitoring period was characterized by higher external temperatures and activation of the ventilation system, which led to an improvement of the PCM discharging process. A better exploitation of the PCM storage capacity was seen during this first period. In the second monitoring period, due to the lower outdoor temperatures, a less evident improvement of the indoor conditions was observed in the components with PCM.

The comparison of the heat fluxes and temperatures between the reference cell (without PCM) and those equipped with Infinite $R^{\mathrm{TM}} 21$ and Infinite $\mathrm{R}^{\mathrm{TM}} 23$ has demonstrated that the adoption of these materials allows both the temperature and the heat flux peaks to be reduced. In particular:

- $\quad \mathrm{PCM}$ Infinite $\mathrm{R}^{\mathrm{TM}} 21$ (room $\mathrm{C}$ ) always shows a higher potential for reducing the peak heat gains (up to $47-48 \%$ for both monitoring periods) and a reduction in the internal surface temperature of the roof of up to $1.5^{\circ} \mathrm{C}$.

- $\quad \mathrm{PCM}$ Infinite $\mathrm{R}^{\mathrm{TM}} 23$ (room B) shows a lower peak heat gain reduction (about 20-40\%, depending on the monitoring period) and reductions in the internal surface temperature of the roof of $\sim 1.2{ }^{\circ} \mathrm{C}$ (test period \#1) and $\sim 0.6^{\circ} \mathrm{C}$ (test period \#2).

These outcomes should clearly be related to the range of the outdoor/indoor temperatures, since the results could change significantly for different climatic conditions or in a different season.

It should be noted that the latent heat capacity of the PCMs was never fully exploited in any of the monitoring periods. Only for PCM Infinite $\mathrm{R}^{\mathrm{TM}} 21$ (Room C) was a partial exploitation seen. Therefore, although some benefits can be highlighted, it is worth mentioning that a better performance can be obtained if the right PCM melting temperature is selected. This leads to the consideration that the melting temperature of PCMs, as well as their quantity and position need to be carefully designed to achieve a better performance and to gain greater benefits, in terms of both the indoor thermal comfort conditions and energy saving. In relation to this latter remark, a graphical tool that is useful to help choose the most promising PCM is proposed in Figures 12 and 16.

In these plots, the trends of the temperature vs. the enthalpy of the PCM, T(h) (for heating and cooling) are "overlapped" onto the trend of the temperature of the component vs. time, $\mathrm{T}$ (time). This allows clear information to be obtained, at a glance, concerning to what extent the potentialities of the phase change process are exploited. In order to 
optimize the behavior of the component, the peaks of function $\mathrm{T}(\mathrm{h})$ should be within the range of fluctuations of the temperature over time, $\mathrm{T}$ (time), as much as possible, in such a way that, at each oscillation, most of the heat of fusion of the PCM is exploited.

The conclusions that have been discussed above are represented in Figure 12a,b and Figure 16a,b. The "overlap" of the two functions, that is, of T(h) and T(time), is significantly higher in Figures $12 b$ and $16 b$ (Infinite $\mathrm{R}^{\mathrm{TM}} 21$, Room C) than in Figures 12a and 16a (Infinite $\mathrm{R}^{\mathrm{TM}} 23$, Room C).

Author Contributions: Conceptualization, S.F., G.A. and E.F.; methodology, S.F., E.S. and G.A.; formal analysis, S.F., E.S., G.A. and E.F.; investigation, S.F., E.S. and G.A.; data curation, S.F., E.S., G.A. and E.F.; writing—original draft preparation, S.F., G.A. and E.F.; writing—review and editing, S.F., M.P. and E.F.; visualization, G.A. and E.F.; supervision, S.F. and M.P. All authors have read and agreed to the published version of the manuscript.

Funding: This research was partially funded by the E4E S.r.l. company in the framework of a consultancy contract with the Politecnico di Torino-Department of Energy, under the scientific responsibility of Stefano Fantucci (2021).

Acknowledgments: The authors wish to thank Mauro Papagni and Davide Franco of E4E S.r.l. for the support provided during the research activities.

Conflicts of Interest: The authors declare no conflict of interest.

\section{References}

1. Kalnæs, S.E.; Jelle, B.P. Phase Change Materials and Products for Building Applications: A State-of-the-Art Review and Future Research Opportunities. Energy Build. 2015, 94, 150-176. [CrossRef]

2. Dutil, Y.; Rousse, D.; Lassue, S.; Zalewski, L.; Joulin, A.; Virgone, J.; Kuznik, F.; Johannes, K.; Dumas, J.-P.; Bédécarrats, J.-P.; et al. Modeling Phase Change Materials Behavior in Building Applications: Comments on Material Characterization and Model Validation. Renew. Energy 2014, 61, 132-135. [CrossRef]

3. Junaid, M.F.; Rehman, Z.; Čekon, M.; Čurpek, J.; Farooq, R.; Cui, H.; Khan, I. Inorganic Phase Change Materials in Thermal Energy Storage: A Review on Perspectives and Technological Advances in Building Applications. Energy Build. 2021, $252,111443$. [CrossRef]

4. Luo, C.; Xu, L.; Ji, J.; Liao, M.; Sun, D. Experimental Study of a Modified Solar Phase Change Material Storage Wall System. Energy 2017, 128, 224-231. [CrossRef]

5. Serale, G.; Fiorentini, M.; Capozzoli, A.; Cooper, P.; Perino, M. Formulation of a Model Predictive Control Algorithm to Enhance the Performance of a Latent Heat Solar Thermal System. Energy Convers. Manag. 2018, 173, 438-449. [CrossRef]

6. Zhu, N.; Li, S.; Hu, P.; Lei, F.; Deng, R. Numerical Investigations on Performance of Phase Change Material Trombe Wall in Building. Energy 2019, 187, 116057. [CrossRef]

7. Sawadogo, M.; Duquesne, M.; Belarbi, R.; Hamami, A.E.A.; Godin, A. Review on the Integration of Phase Change Materials in Building Envelopes for Passive Latent Heat Storage. Appl. Sci. 2021, 11, 9305. [CrossRef]

8. Ostry, M.; Charvat, P. Materials for Advanced Heat Storage in Buildings. Procedia Eng. 2013, 57, 837-843. [CrossRef]

9. Cabeza, L.F.; Castell, A.; Barreneche, C.; de Gracia, A.; Fernández, A.I. Materials Used as PCM in Thermal Energy Storage in Buildings: A Review. Renew. Sustain. Energy Rev. 2011, 15, 1675-1695. [CrossRef]

10. Konuklu, Y.; Ostry, M.; Paksoy, H.O.; Charvat, P. Review on Using Microencapsulated Phase Change Materials (PCM) in Building Applications. Energy Build. 2015, 106, 134-155. [CrossRef]

11. Kośny, J. PCM-Enhanced Building Components; Engineering Materials and Processes; Springer International Publishing: Cham, Switzerland, 2015; ISBN 978-3-319-14285-2.

12. Bečkovský, D.; Ostrý, M.; Kalábová, T.; Tichomirov, V. Thermal Stability of Attic Spaces with Integrated PCMs during the Climatic Year. AMR 2013, 649, 175-178. [CrossRef]

13. Charvat, P.; Mauder, T.; Ostry, M. Simulation of latent-heat thermal storage integrated with room structures. Mater. Tehnol. 2012, 46, 239-242.

14. Purohit, B.K.; Sistla, V.S. Inorganic Salt Hydrate for Thermal Energy Storage Application: A Review. Energy Storage 2021, 3, e212. [CrossRef]

15. Fantucci, S.; Serra, V. Investigating the Performance of Reflective Insulation and Low Emissivity Paints for the Energy Retrofit of Roof Attics. Energy Build. 2019, 182, 300-310. [CrossRef]

16. Elarga, H.; Fantucci, S.; Serra, V.; Zecchin, R.; Benini, E. Experimental and Numerical Analyses on Thermal Performance of Different Typologies of PCMs Integrated in the Roof Space. Energy Build. 2017, 150, 546-557. [CrossRef]

17. Pasupathy, A.; Velraj, R. Effect of Double Layer Phase Change Material in Building Roof for Year Round Thermal Management. Energy Build. 2008, 40, 193-203. [CrossRef] 
18. Alqallaf, H.J.; Alawadhi, E.M. Concrete Roof with Cylindrical Holes Containing PCM to Reduce the Heat Gain. Energy Build. 2013, 61, 73-80. [CrossRef]

19. Boobalakrishnan, P.; Manoj Kumar, P.; Balaji, G.; Jenaris, D.S.; Kaarthik, S.; Jaya Prakash Babu, M.; Karthhik, K. Thermal Management of Metal Roof Building Using Phase Change Material (PCM). Mater. Today Proc. 2021, 47, 5052-5058. [CrossRef]

20. Al-Yasiri, Q.; Szabó, M. Experimental Investigation of Phase Change Material (PCM) Incorporated Composite Flat Roof for Energy-Saving under Iraq Hot Climate Conditions; AIP Publishing: Samawa, Iraq, 2021; p. 080015.

21. Thongtha, A.; Janyoosuk, K.; Mano, C. Integration of Phase Change Material into Fiber Cement Roof for Reduction of Heat Accumulation in Buildings. ScienceAsia 2021, 47S, 83. [CrossRef]

22. ASTM E793-06; Standard Test Method for Enthalpies of Fusion and Crystallization by Differential Scanning Calorimetry. 2018. Available online: https:/ / www.astm.org/e0793-06r18.html(accessed on 23 November 2021).

23. Biswas, K.; Shukla, Y.; Desjarlais, A.; Rawal, R. Thermal Characterization of Full-Scale PCM Products and Numerical Simulations, Including Hysteresis, to Evaluate Energy Impacts in an Envelope Application. Appl. Therm. Eng. 2018, 138, 501-512. [CrossRef]

24. Shukla, N.; Kosny, J. DHFMA Method for Dynamic Thermal Property Measurement of PCM-Integrated Building Materials. Curr. Sustain. Renew. Energy Rep. 2015, 2, 41-46. [CrossRef]

25. Ruuska, T.; Vinha, J.; Kivioja, H. Measuring Thermal Conductivity and Specific Heat Capacity Values of Inhomogeneous Materials with a Heat Flow Meter Apparatus. J. Build. Eng. 2017, 9, 135-141. [CrossRef]

26. Tleoubaev, A.; Brzezinski, A. Title: Thermal Diffusivity and Volumetric Specific Heat Measurements Using Heat Flow Meter Instruments for Thermal Conductivity 29 Thermal Expansion 17 Conference. Therm. Expans. 2007, 17, 10.

27. Fantucci, S.; Goia, F.; Perino, M.; Serra, V. Sinusoidal Response Measurement Procedure for the Thermal Performance Assessment of PCM by Means of Dynamic Heat Flow Meter Apparatus. Energy Build. 2019, 183, 297-310. [CrossRef]

28. ASTM C1784:2020; Standard Test Method for Using a Heat Flow Meter Apparatus for Measuring Thermal Storage Properties of Phase Change Materials and Products. ASTM International: West Conshohocken, PA, USA, 2020.

29. Insolcorp. Available online: Https:/ / Insolcorp.Com/ (accessed on 23 November 2021).

30. EN 12664:2001; Thermal Performance of Building Materials and Products. Determination of Thermal Resistance by Means of Guarded Hot Plate and Heat Flow Meter Methods-Dry and Moist Products of Medium and Low Thermal Resistance. CEN European Committee for Standardization: Bruxelle, Belgium, 2001.

31. Lane, G.A. Low Temperature Heat Storage with Phase Change Materials. Null 1980, 1, 155-168. [CrossRef]

32. Kenisarin, M.; Mahkamov, K. Salt Hydrates as Latent Heat Storage Materials:Thermophysical Properties and Costs. Solar Energy Mater. Solar Cells 2016, 145, 255-286. [CrossRef]

33. Farid, M.M.; Khudhair, A.M.; Razack, S.A.K.; Al-Hallaj, S. A Review on Phase Change Energy Storage: Materials and Applications. Energy Convers. Manag. 2004, 45, 1597-1615. [CrossRef]

34. Gschwander, S.; Lazaro, A.; Cabeza, L.F.; Günther, E.; Fois, M.; Chui, J. Development of a Test Standard for PCM and TCM Characterization-Part 1: Characterization of Phase Change Materials; IEA Solar Heating and Cooling Programme; International Energy Agency: Paris, France, 2011. 